\title{
Cellulose and its derivatives: towards biomedical applications
}

\author{
Hadi Seddiqi (D) - Erfan Oliaei (D) - Hengameh Honarkar (D) - Jianfeng Jin (iD) -

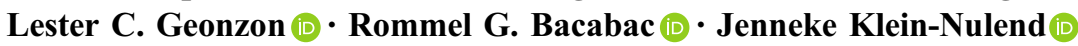

Received: 24 June 2020/Accepted: 29 December 2020/Published online: 27 January 2021

(C) The Author(s) 2021

\begin{abstract}
Cellulose is the most abundant polysaccharide on Earth. It can be obtained from a vast number of sources, e.g. cell walls of wood and plants, some species of bacteria, and algae, as well as tunicates, which are the only known cellulosecontaining animals. This inherent abundance naturally paves the way for discovering new applications for this versatile material. This review provides an
\end{abstract}

Shared first authorship: Hadi Seddiqi and Erfan Oliaei contributed equally to this manuscript.

Shared last authorship: Rommel G. Bacabac and Jenneke Klein-Nulend contributed equally to this manuscript.

H. Seddiqi · J. Jin · J. Klein-Nulend $(\bowtie)$

Department of Oral Cell Biology, Academic Centre for Dentistry Amsterdam (ACTA), University of Amsterdam and Vrije Universiteit Amsterdam, Amsterdam Movement Sciences, Gustav Mahlerlaan 3004, 1081 LA Amsterdam, The Netherlands

e-mail: j.kleinnulend@acta.nl

H. Seddiqi

e-mail: seddiqi.hadi@gmail.com

J. Jin

e-mail: j.jin@acta.nl

E. Oliaei

Bioeconomy and Health Division, Material and Surface Design Department, Research Institutes of Sweden (RISE), Drottning Kristinas väg 61, 11486 Stockholm, Sweden

e-mail: erfan.oliaei@mail.com extensive survey on cellulose and its derivatives, their structural and biochemical properties, with an overview of applications in tissue engineering, wound dressing, and drug delivery systems. Based on the available means of selecting the physical features, dimensions, and shapes, cellulose exists in the morphological forms of fiber, microfibril/nanofibril, and micro/nanocrystalline cellulose. These different cellulosic particle types arise due to the inherent diversity among the source of organic materials or due to the specific conditions of biosynthesis and processing that determine the consequent geometry and dimension of cellulosic particles. These different

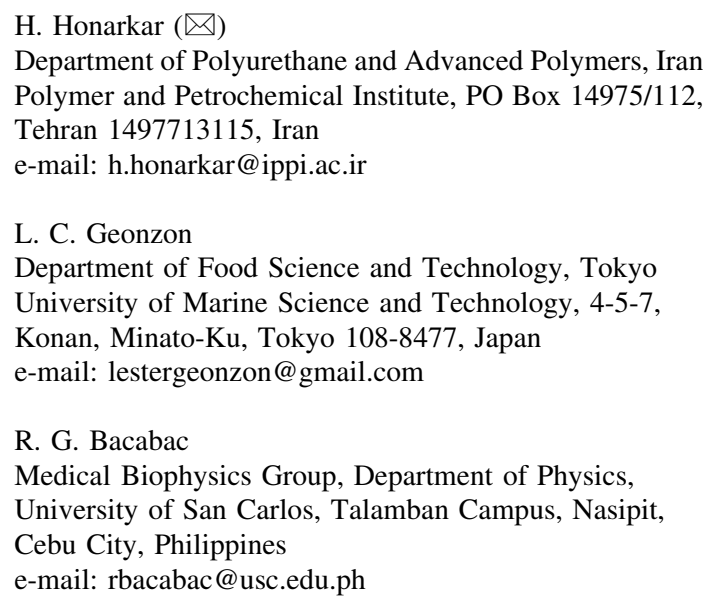


cellulosic particles, as building blocks, produce materials of different microstructures and properties, which are needed for numerous biomedical applications. Despite having great potential for applications in various fields, the extensive use of cellulose has been mainly limited to industrial use, with less early interest towards the biomedical field. Therefore, this review highlights recent developments in the preparation methods of cellulose and its derivatives that create novel properties benefiting appropriate biomedical applications.

Keywords Biomedical applications .

Cellulose $\cdot$ Cellulose derivatives · Drug delivery ·

Tissue engineering $\cdot$ Wound dressing

\section{Introduction}

The increasing demand for bio-based materials is gaining more attention for immediate applications in biomedical fields such as tissue engineering, wound healing, and drug delivery. Polysaccharides, longchain biopolymeric carbohydrate molecules primarily composed of monosaccharide units, are bio-based materials that combine immense potential in biomedical applications with the unique beneficial features of natural polymers in contrast with synthetic polymers. Among several kinds of polysaccharides, cellulose and chitin are the most important natural biopolymers based on their broad distribution in nature. Cellulose is synthesized mostly in wood and plants, whereas chitin is obtained from lower animals (Barikani et al. 2014; Moon et al. 2011). In this review paper, we focus on the characteristics, preparation methods, and application of cellulose and its derivatives in the biomedical field.

Cellulose is an unbranched, natural polymer composed of repeating glucose units $\left(\mathrm{C}_{6} \mathrm{H}_{10} \mathrm{O}_{5}\right)_{n}$ (French 2017), and is considered as the most profuse organic material and polysaccharide on Earth. This biodegradable polymer is mostly found in nature in the form of microfibrils in the cell walls of wood and plant, algae tissues, and membrane of epidermal cells of tunicate. It is also synthesized by bacteria in the form of nanofiber networks. Cellulosic materials exploit hierarchical structure design that spans from nanoscale to macroscopic dimensions in the form of fibril aggregates, fibrils, nanocrystallite, and nanoscale disordered domains (Fig. 1a,b). Cellulose features an intricate multi-level structure, built up of bundles/aggregates of superfine fibrils. The superfine fibril contains several cellulose chains (Fig. 1a). Each fibril is composed of repeating large ordered (crystalline) domains and small disordered (amorphous) domains with a cross-sectional dimension ranging from 2 to $20 \mathrm{~nm}$, depending on the source of synthesis (Fig. 1b) (Ioelovich 2008). A single cellulose chain passes through many crystalline and disordered domains, while strong $\beta 1 \rightarrow 4$ glycosidic bonds link single cellulose chain units. Cellulose chains are remarkably aligned in the crystalline domain of a cellulose fibril (Klemm et al. 2018, 2011).

Cellulose and its derivatives, as biocompatible polymers, have attracted considerable attention for applications in the biomedical field due to suitable physical and mechanical properties. Cellulose naturally develops functionality, flexibility, and high specific strength by exploiting hierarchical structure (Ansari et al. 2015; Moon et al. 2011). It also has low density, low price, as well as biodegradability (Fidale et al. 2013). Cellulosic materials enable tuning of porosity and interconnectivity desirable for targeting biomedical applications (Sultan and Mathew 2018). Nevertheless, cellulose has several less favorable
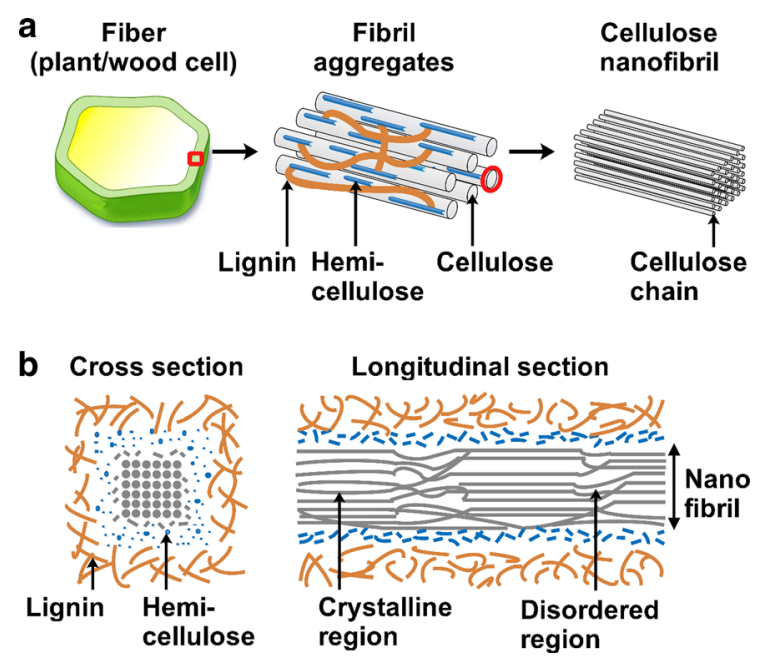

Fig. 1 Schematic illustration of the microstructure of a cellulosic fiber. a Plant/wood fiber, fibril aggregate, and nanofibril (containing cellulose chains) associated with lignin and hemicellulose. b Cross section and longitudinal section showing the crystalline and disordered regions of a cellulose nanofibril embedded in lignin and hemicellulose matrix 
properties for application in the biomedical field like moisture sensitivity, insolubility in water and most common solvents, and low resistance against microbial attacks (Dumitriu et al. 2018; Tilki et al. 2010). However, cellulose can be chemically modified by substitution of its native hydroxyl groups with functional groups, such as specific acids, chlorides, and oxides, to address less favorable properties or to develop new desired characteristics.

Traditionally, cellulosic materials have been used in industries for developing paper and textile (Karmazsin 1987), while in the last decades, cellulosic materials have been used for a variety of applications, e.g. biomedical applications (Ates et al. 2020; Trache et al. 2020). Cellulosic materials especially show great promise as cost-effective forward-looking materials for biomedical applications because of their biocompatibility, biodegradability, and low cytotoxicity. Moreover, due to their chemical functionality, cellulosic materials can be easily modified to yield useful products. Cellulosic materials play an essential role in traditional disease control and health care. Meanwhile, many new application areas are also explored, such as tissue engineering (Ninan et al. 2013), wound treatment (Solway et al. 2011), and drug delivery (Gunduz et al. 2013). In the current review, the results of detailed studies on cellulose from various sources and the preparation of cellulose derivatives, as well as their applications as novel biomedical substances in the field of tissue engineering, wound dressing, and drug delivery systems are presented.

\section{Cellulose structure}

Cellulose is a high molecular weight unbranched chain, homo-biopolymer with repeating D-glucose units, linked together by $\beta 1 \rightarrow 4$ glycosidic bonds (Brown et al. 1996; Habibi et al. 2010). One end of the cellulose chain is reduced to a hemiacetal functionality (Habibi et al. 2010; Moon et al. 2011). The structure of cellulose is complicated due to different packing and aggregation of the cellulose chains, which varies among cellulose producing organisms. Cellulose has three hydroxyl groups in each glucose residue with a degree of polymerization based on glucose units ranging from 1000 to 15,000, depending on the cellulose origin and treatments
(Table 1). The intra-chain hydrogen bonding between hydroxyl groups and oxygen of the adjoining ring of cellulose molecules stabilizes the linkage and results in a unbranched conformation of cellulose chains (Agoda-Tandjawa et al. 2010).

Cellulose molecules assemble in the form of ordered parallel layers into elementary fibrils, either in plant cell walls, algae cell walls, tunicate epidermal cell membranes, or produced by bacteria. Linked by van der Waals forces and strong intra- and/or intermolecular hydrogen bonds, the cellulose chains are tightly aggregated together with a lateral dimension of 3-5 nm. Each elementary fibril is a bundle of cellulosic crystals along the fibril axis alternated with disordered domains. Bundles of elementary fibrils further constitute cellulose microfibrils with a crosssectional width of 5-20 nm and a length of several micrometers, depending on their origin (Klemm et al. 2005).

Cellulose is a semi-crystalline material, and its degree of crystallinity depends on its origin, extraction method, and pretreatment. The degree of crystallinity of wood-based and plant-based cellulose usually ranges from 40 to $60 \%$, while cellulose from other sources, like bacteria and tunicin, shows a higher degree of crystallinity ranging from 80 to 100\% (Avolio et al. 2012; Moon et al. 2011; Müller et al. 2014). Crystalline cellulose exists in the allomorphs of cellulose I, II, III, and IV (Moon et al. 2011), which are discussed below.

Cellulose I, II, III, and IV

The different allomorphs of crystalline cellulose are cellulose I, II, III, and IV (Ishikawa et al. 1997). Cellulose I contains parallel chains in the crystalline structure and is naturally derived from a variety of sources (trees, plants, tunicates, algae, and bacteria) (Wada et al. 2010). Cellulose I forming sheets, which are stacked together by hydrogen bonds and Van der Waals interactions (Wada et al. 2010), contribute significantly to the stiffness and specific structure of cellulose.

The crystalline phase of cellulose I is composed of two metastable structures, i.e. triclinic $(\mathrm{I} \alpha)$ and monoclinic (I $\beta)$. The ratio of $\mathrm{I} \alpha$ to $\mathrm{I} \beta$ structures depends on the source of cellulose. The I $\alpha$ structure with a triclinic unit cell is the allomorph known for most algal and bacterial cellulose (Wada et al. 2010). 
Table 1 Degree of polymerization of cellulose from various sources

\begin{tabular}{|c|c|c|c|}
\hline Source & Type & $\begin{array}{l}\text { Degree of } \\
\text { polymerization } \\
\text { (range) }\end{array}$ & Reference(s) \\
\hline \multirow[t]{3}{*}{ Wood } & $\begin{array}{l}\text { Wood from } \\
\text { various } \\
\text { species }\end{array}$ & $6000-10,000$ & Hallac and Ragauskas (2011) \\
\hline & $\begin{array}{l}\text { Wood pulp (in } \\
\text { general) }\end{array}$ & $2000-4000$ & $\begin{array}{l}\text { Henriksson et al. (2007), Sehaqui et al. (2011), Shimizu et al. (2016), Sjöström } \\
\text { and Westermark (1999) }\end{array}$ \\
\hline & Wood CNF & $250-3500$ & $\begin{array}{l}\text { Benítez and Walther (2017), Guo et al. (2017), Henriksson et al. (2007, 2008), } \\
\text { Kurihara and Isogai (2015), Shinoda et al. (2012) }\end{array}$ \\
\hline \multirow[t]{7}{*}{ Plant } & Cotton & $10000-15,000$ & Hallac and Ragauskas (2011), Kumar et al. (2009) \\
\hline & Corn & 1700 & Xu et al. (2009) \\
\hline & Wheat straw & 2600 & Jahan and Mun (2009) \\
\hline & Jute & 1900 & Jahan and Mun (2009) \\
\hline & Bagasse & 1000 & Hallac and Ragauskas (2011) \\
\hline & Corn stover & 2500 & Hallac and Ragauskas (2011) \\
\hline & Corn kernel & 1700 & Hallac and Ragauskas (2011) \\
\hline Bacteria & & $7000-16,000$ & Hallac and Ragauskas (2011), Tahara et al. (1997) \\
\hline Algae & & $2500-4300$ & Guo et al. (2017), Hallac and Ragauskas (2011) \\
\hline Tunicate & & $700-3500$ & Šturcová et al. (2005), Zhao and Li (2014), Zhao et al. (2015b) \\
\hline
\end{tabular}

The values of degree of polymerization are estimated by different methods including number-average (DPn), weight-average (DPw), and viscosity-average (DPv)

The I $\beta$ allomorph has a monoclinic unit cell containing two parallel chains, which is typically found in plant-based and tunicate-based cellulose (Yamamoto et al. 1996). The I $\alpha$ structure can be partly converted into the I $\beta$ structure (Debzi et al. 1991; Horikawa and Sugiyama 2009), through hydrothermal treatment in alkaline solution at $260{ }^{\circ} \mathrm{C}$ or through high-temperature treatment in helium gas and organic solvents (Debzi et al. 1991).

The thermodynamically metastable cellulose I can be converted into either cellulose II or III (Fig. 2). Up to now, cellulose II is considered to have the most stable structure, specifically a monoclinic structure, that provides technical relevance for its use. Conversion of cellulose I into cellulose II was discovered by John Mercer in 1844, during the treatment of cotton by an alkaline solution (Heines 1944). Cellulose II is typically obtained by regeneration (dissolution and recrystallization) or mercerization (aqueous sodium hydroxide treatment) of native cellulose (Wada et al. 2010). During this conversion, the parallel chain arrangement of cellulose I changes into a more stable antiparallel chain arrangement of cellulose II.

Cellulose III can be formed from cellulose I or II through liquid ammonia treatment, and is called cellulose $\mathrm{III}_{\mathrm{I}}$ and $\mathrm{III}_{\mathrm{II}}$, respectively (Fig. 2).

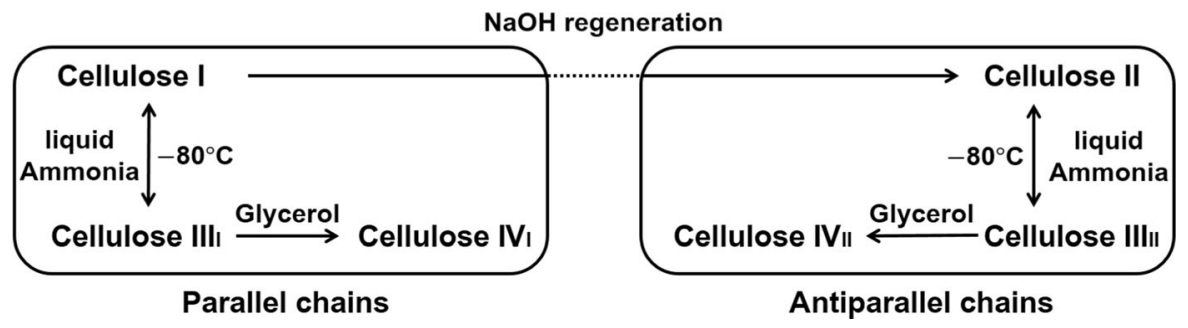

Fig. 2 Phase transition between various crystalline allomorphs of cellulose (cellulose I, II, III, and IV) 
Subsequent thermal treatments can be applied to form cellulose IV from both cellulose III $_{\mathrm{I}}$ and $\mathrm{III}_{\mathrm{II}}$ (Nishiyama et al. 2002; Wada et al. 2010) (Fig. 2).

\section{Cellulose sources}

Cellulose is categorized based on its source of origin, i.e. as wood-based cellulose (WC), plant-based cellulose (PC), bacteria-based cellulose (BC), algaebased cellulose, and tunicate-based cellulose (Fig. 3). In the long history of cellulose use, based on its abundance and cost-effectiveness, WC and PC became the most commonly known kinds of cellulose in contrast with $\mathrm{BC}$, tunicate-based cellulose, and algae-based cellulose (Klemm et al. 2011).

Wood and plant cellulose

Cellulose has been extracted from softwood (such as pine (Bilbao et al. 1997), cedar (Shi et al. 2015), and spruce (Fernandes et al. 2011)) and hardwood (such

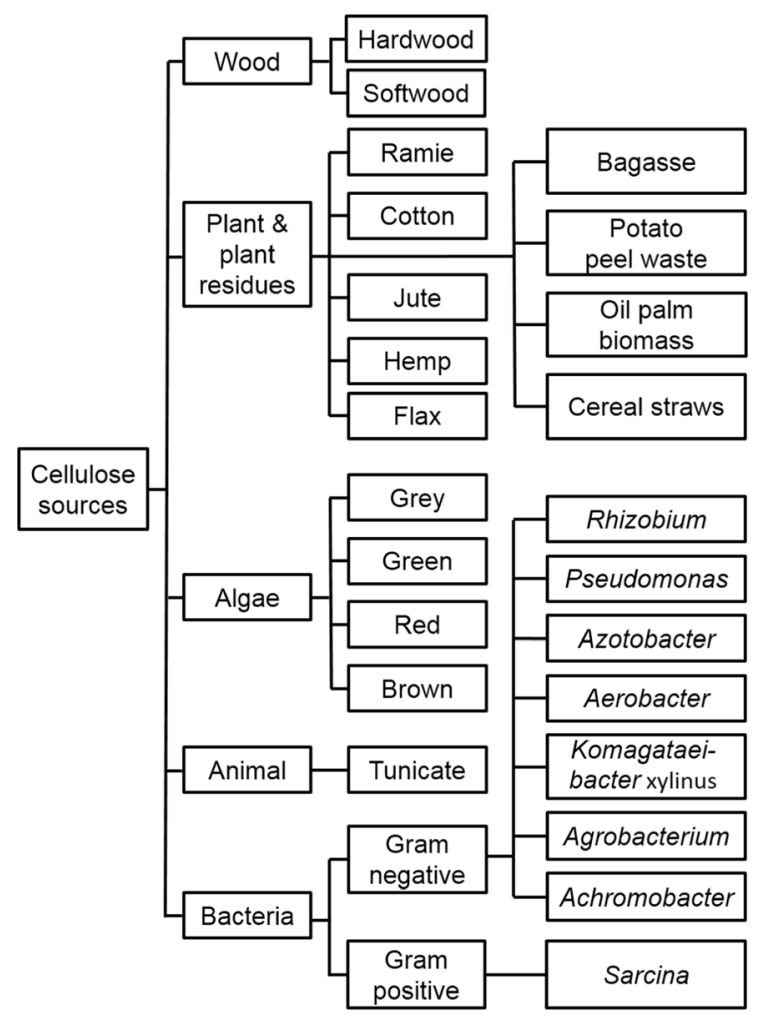

Fig. 3 Classification of cellulose according to source: wood, plant, algae, animal (tunicate), and bacteria as oak (Robertson et al. 1997), and beech (Uehara and Sakata 1990)). Furthermore, a wide variety of plant materials has been studied for the extraction of cellulose including cotton (Nam et al. 2020), flax (Yu et al. 2015), pineapple leaf (Balakrishnan et al. 2018a, b), corn (Gopi et al. 2017), hemp, jute, bagasse, ramie (Nishiyama et al. 2003), cereal straws (Vargas et al. 2012), potato peel waste (Chen et al. 2012), and oil palm biomass (Haafiz et al. 2013) (Fig. 3).

Fibers extracted from wood and plant show similarities in composition and structure, including biodegradable carbohydrate polymers, mainly cellulose, hemicellulose, and lignin (Table 2). Cellulose molecules in either wood or plant have a complex, multi-level structure (Fig. 4); they are linked to other biopolymers like hemicellulose and lignin (Bidlack and Buxton 1992; Herranz et al. 1981; Ramsden and Blake 1997) (Fig. 1a,b). Although cellulose from plants and wood has the same chemical structure as that from other sources, it has a different microstructural organization (Martínez-Sanz et al. 2011). In WC and PC, cellulose chains are packed in layers as nanofibrils, held together by hemicellulose and lignin matrix (Fig. 1a, b). Although cotton fiber is PC, it does not have lignin or hemicellulose to a significant extent. The cellulose content in plants is generally $30-75 \%$ and in wood 40-50\% (Parveen Kumar 2009; Shahzadi et al. 2014; Sun and Cheng 2002) (Table 2). Softwood and hardwood differ in chemical composition, i.e. they differ in the content of cellulose, hemicellulose, and lignin (Table 2), and in structural organization.

\section{Bacterial cellulose}

The cellulose produced by bacteria is called "microbial cellulose", "bacterial nanocellulose", "biocellulose" or specifically "bacterial cellulose". BC was first discovered by Brown in 1886 as a strong jelly membrane on the surface of a vinegar fermentation broth (Brown 1886). BC is synthesized by terminal complex in almost pure form (>90\%) without binding to any other polymer, e.g. lignin and hemicellulose (Fig. 5). Therefore, the isolation and purification of $\mathrm{BC}$ are quite simple and do not need extensive chemical or any other type of treatment, in contrast with WC and PC. Since its discovery, BC has attracted attention due to several 
Table 2 Content of cellulose, hemicellulose, and lignin as major components in the chemical composition of wood and plant fibers

\begin{tabular}{lllll}
\hline Source & Type & $\begin{array}{l}\text { Cellulose (wt. } \\
\%)\end{array}$ & $\begin{array}{l}\text { Hemicellulose (wt. Lignin (wt. } \\
\%)\end{array}$ & Reference(s) \\
\hline $\begin{array}{l}\text { Plant fibers (except } \\
\text { cotton) }\end{array}$ & $30-75$ & $10-35$ & $0-20$ & $\begin{array}{c}\text { Madsen and Gamstedt 2013, Thygesen et al. } \\
2005\end{array}$ \\
$\begin{array}{l}\text { Wood fibers } \\
\text { Softwood }\end{array}$ & $45-50$ & $18-35$ & $23-35$ & $\begin{array}{c}\text { Madsen and Gamstedt 2013 } \\
\text { Liitiä et al. 2003, Madsen and Gamstedt } \\
\text { 2013 }\end{array}$ \\
\hline
\end{tabular}

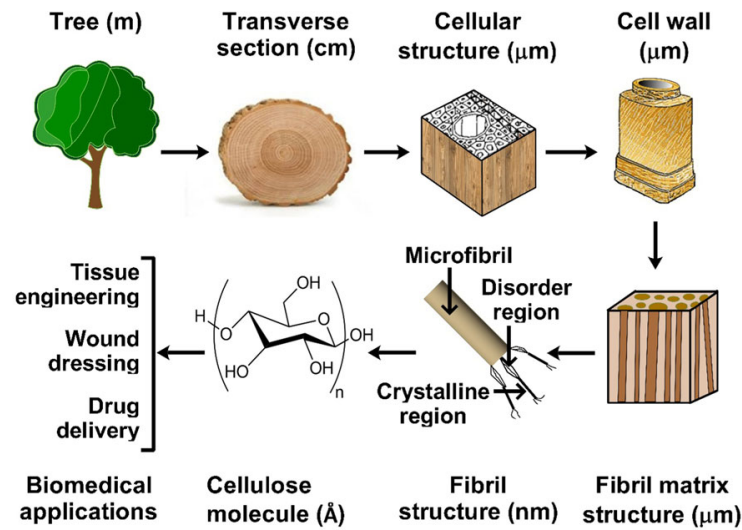

Fig. 4 Schematic of wood structure from tree to cellulose molecule, and major biomedical applications

advantages such as high purity, ultrafine fibers shapes, remarkably crystalline structure, high mechanical strength, biodegradability, biocompatibility, high water-holding capability, conducive chemical stability, and a high degree of polymerization (Campano et al. 2016). More importantly, BC is considered a non-cytotoxic, non-genotoxic, and highly biocompatible material, attracting interest in diverse areas with hallmarks in medicine (Gorgieva and Trček 2019).

BCs are mainly produced extracellularly by Gram negative bacteria such as Komagataeibacter xylinus, Agrobacterium, Achromobacter, Aerobacter, Azotobacter, Pseudomonas, and Rhizobium, and only one genus of Gram positive bacteria namely Sarcina (Fig. 3) (Hong and Qiu 2008; Jonas and Farah 1998) with oxygen supply (air) and a carbon source (mainly D-glucose), as well as a nitrogen source (Jozala et al. 2015; Klemm et al. 2011). Komagataeibacter xylinus (formerly Acetobacter xylinum) is the most widely used species of bacteria for producing $\mathrm{BC}$ since it produces relatively large amounts of $\mathrm{BC}$ from a wide range of carbon and nitrogen sources in liquid culture (Hong and Qiu 2008; Zhong et al. 2013). Carbon sources used for this purpose are commonly agroindustrial wastes, e.g. rotten fruit like pineapple peels juice and sugar as a medium (Castro et al. 2011; Jozala et al. 2015). The yield of BC synthesis is up to $40 \%$ in relation to the starting carbon source, although, generally, the large-scale production of $\mathrm{BC}$ is costly (Klemm et al. 2011).

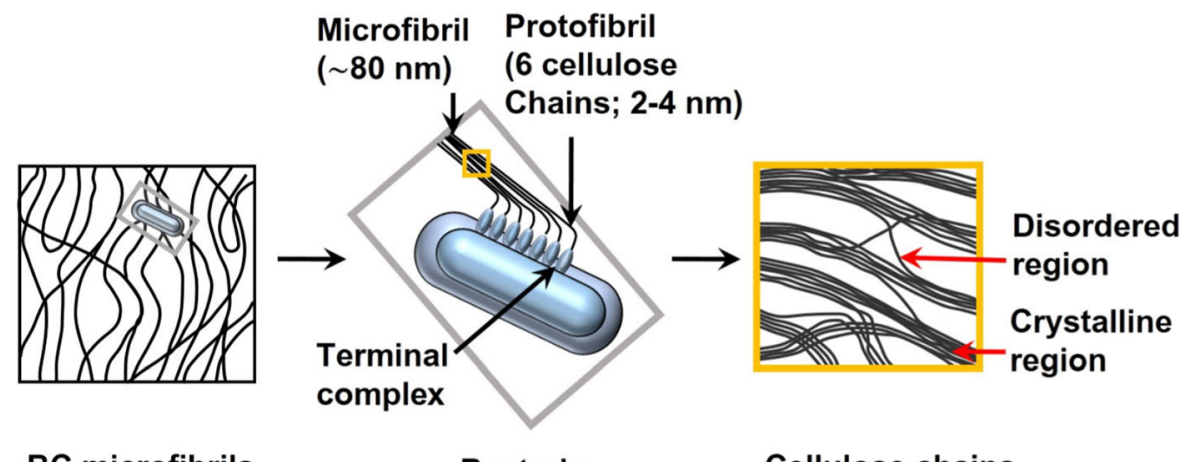

BC microfibrils

Bacteria

\section{Cellulose chains}

Fig. 5 Schematic of bacterial cellulose network representing terminal complex, microfibrils, protofibrils, and crystalline and disordered regions of cellulose chains 
The main characteristics of $\mathrm{BC}$ are the high degree of crystallinity (80-90\%), the high degree of polymerization (in the range of 7000-16000 glucose residues; Table 1), and high mechanical strength associated with inherent single cellulose nanofibers (at the order of the specific strength of steel or Kevlar). BC can be processed into the morphological forms of fleeces, films, spheres, and hollow particles (Müller et al. 2014), which make it versatile for biomedical materials design. Although WC, PC, and BC have the same chemical building blocks, they differ in mechanical properties due to their difference in structural organization (Martínez-Sanz et al. 2011) (Table 4). Furthermore, the degradation rate of $\mathrm{BC}$ is slightly higher than that of WC and PC (Castro et al. 2011; Klemm et al. 2011). BC is synthesized in a variety of synthetic and non-synthetic media by a class of acetic acid-generating bacteria. During biosynthesis, $\mathrm{BC}$ forms a pellicle of a random nanofibrillar network of cellulose chains composed of crystalline and disordered regions (Koizumi et al. 2008) (Fig. 5). Moreover, BC takes up enormous amounts of water (in some cases, more than 99\% water), and produces stable hydrogels. Well-separated BC nanofibers have large surface areas forming an extremely porous structure (Chen et al. 2009). BC consists of randomly assembled, $<100 \mathrm{~nm}$ wide ribbon-shaped fibrils, composed of 7-8 nm wide elementary nanofibrils aggregated in bundles (Gorgieva and Trček 2019; Li et al. 2016a). This unique nano-morphology results in a large surface area that can hold a large amount of water, and at the same time displays excellent elasticity, high wet strength, and conformability (Gorgieva and Trček 2019). The combination of the advantageous properties of $\mathrm{BC}$ has become an exciting feature for biomedical applications, especially in tissue engineering and in the pharmaceutical industry, as implants and scaffolds, emulsion and hydrogel stabilizers, drug-delivery systems, smart artificial skin or wound regeneration therapies, and enzyme and biomolecules immobilization for enhanced activity and higher stability in vivo.

\section{Algal cellulose}

Various types of algae, e.g. brown species (Posidonia Oceanica) (Tarchoun et al. 2019), green species (Cladophora) (Pan et al. 2016), and red species (Gelidium elegans) (Chen et al. 2016b) (Fig. 3), are other important sources of cellulose, with the algae cell walls made up of a large portion of cellulose. Red algae (like Gelidium elegans) have a rich content of carbohydrates, which are mainly composed of an energydense substrate (cellulose) and mucilaginous materials (agar). Algae are alternative renewable sources for cellulose production since they can receive nutrients from waste streams (i.e. wastewater, flue gas), and be cultivated at a large scale ultimately benefitting the environment (Aysu et al. 2016). Valonia- or Cladophora-derived cellulose has a remarkably high degree of crystallinity ( $>95 \%$ ) (Sugiyama et al. 1991). Algal cellulose is not pure, and is associated mainly with hemicellulose, protein, and lignin (Rabemanolontsoa and Saka 2013).

Cellulose extracted from green algae has unprecedented advantages over WC, PC, and BC because of its high crystallinity ( $>70 \%$ ) (Chen et al. 2016b), low moisture adsorption capacity, high porosity in the mesoporous range, and associated high specific surface area (Strømme et al. 2002; Zhou et al. 2019). Overall, algal nanocellulose has excellent potential for biomedical applications such as tissue engineering because of its nontoxicity, and facile chemical modification (Hua et al. 2016).

Tunicate cellulose

Tunicates are invertebrate animals living in the oceans in vast numbers and are the only known animal source of cellulose (Fig. 3). There are several enzyme complexes in the plasma membrane of tunicate epidermal cells responsible for cellulose synthesis. Tunicate-based cellulose is obtained from the outer tissue of tunicate, named "tunic", from which a pure form of cellulose termed "tunicin" can be extracted (Zhu et al. 2018b). The purified extracted cellulose from tunic is called tunicate cellulose or tunicin. Most of the research in this field has focused on a class of tunicates known as Ascidiacea (sea squirts), which includes over 2300 species (Zhao and Li 2014).

Hundreds of cellulose nanofibrils are bundled in the tunic (Kimura et al. 2001). The shape and dimensions of a nanofibril bundle vary depending on the species. Nanofibril bundles are deposited in a multi-layered texture parallel to the surface of the epidermis. The length of tunicate cellulose nanofibrils ranges from $100 \mathrm{~nm}$ to several micrometers (typically $>2 \mu \mathrm{m}$ ), the width ranges from 10 to $30 \mathrm{~nm}$ (Table 3), and the aspect ratio ranges from 60 to 70 (Zhao et al. 2015b). 
Table 3 Typical dimensions of nanocellulose from various sources

\begin{tabular}{lllll}
\hline $\begin{array}{l}\text { Nanocellulose } \\
\text { type }\end{array}$ & Source & $\begin{array}{l}\text { Length } \\
(\mathrm{nm})\end{array}$ & $\begin{array}{l}\text { Width } \\
(\mathrm{nm})\end{array}$ & Reference(s) \\
\hline Nanofibril & Wood & $>1000$ & $2-100$ & Dufresne (2013), Gumrah Dumanli (2017) \\
& Plant & $>1000$ & $\begin{array}{l}3-100 \\
\text { Chinga-Carrasco (2011), Zambrano et al. (2020) }\end{array}$ \\
& Bacteria & $\begin{array}{c}\text { Different } \\
\text { networks }\end{array}$ & $\begin{array}{c}20- \\
100\end{array}$ & Klemm et al. (2018) \\
& Tunicate & $>2000$ & $10-30$ & Zhao and Li (2014), Zhao et al. (2017), Zhao et al. (2015b) \\
CNC & Wood & $100-200$ & $3-6$ & Klemm et al. (2011), Peciulyte et al. (2015) \\
& Plant & $100-500$ & $3-30$ & de Rodriguez et al. (2006), Habibi et al. (2008), Li et al. (2009) \\
& Bacteria & $100-1000$ & $10-50$ & Araki and Kuga (2001), Roman and Winter (2004), Sacui et al. (2014) \\
& Algae & $>1000$ & $5-30$ & Moon et al. (2011), Revol (1982) \\
& Tunicate & $100-2000$ & $5-30$ & Elazzouzi-Hafraoui et al. (2008), Habibi et al. (2006), Jalal Uddin et al. (2011), \\
& & & Rusli et al. (2011), Śturcová et al. (2005), Zhao et al. (2015b)
\end{tabular}

Generally dry tunic contains approximately $60 \%$ cellulose and $27 \%$ nitrogen-containing components (Berrill 1947). However, after treatment and extraction, tunicate cellulose is highly crystalline (ca. 95\%) composed of nearly pure cellulose in the morphological form of high aspect ratio fibrils (Zhao and $\mathrm{Li}$ 2014). Tunicate cellulose has a high specific surface area ranging from 150 to $170 \mathrm{~m}^{2} / \mathrm{g}$ (Sturcová et al. 2005). It also has a reactive surface due to hydroxyl groups (Šturcová et al. 2005). The degree of polymerization of tunicate cellulose has been reported to be in the range of 700-3500 (Table 1).

\section{Various morphological forms of cellulosic particles}

Cellulose naturally exists or is isolated from various sources in some predetermined dimension and shape, which can simply be classified into cellulose fibers, cellulose filaments, cellulose crystals, and cellulose micro/nanofibrils (Fig. 6). Each cellulosic particle type has a distinguished size, morphology, aspect ratio, crystallinity, and physiochemical properties. These cellulosic particles are discussed below.

\section{Cellulose fibers}

At the site of biosynthesis of wood or plants, cellulose is synthesized as microfibrils that are further organized to assemble cellulose fibers (Fig. 1a). Cellulosic fibers are typically found in three
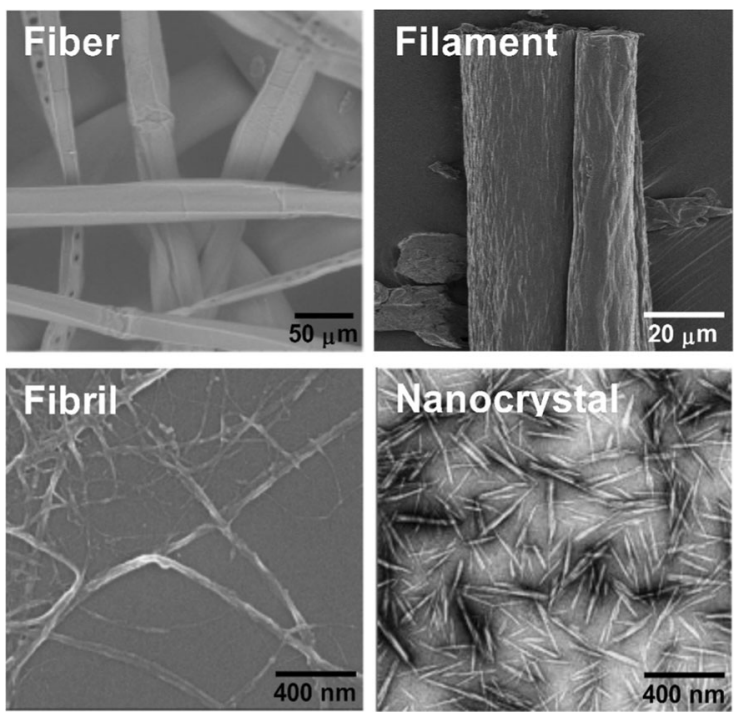

Fig. 6 Cellulosic particles in different forms: fiber [with permission: (Oliaei et al. 2020)], filament [with permission: (Håkansson et al. 2014)], micro/nanofibril, and nanocrystal [with permission: (Habibi et al. 2008)]

geometries, i.e. strand fibers (long fibers of 20-100 cm length), staple fibers (short fibers of $<$ $60 \mathrm{~mm}$ length), and pulp fibers (very short fibers of 1-10 mm length) (Ardanuy et al. 2015). A staple fiber is an entire but single cell, while a strand fiber is composed of many cells. Cotton fibers are staple fibers, with a length of $25-45 \mathrm{~mm}$. The length of cotton linters, i.e. the fibers that remain adhered to the cotton seed, is only a few millimeters. Strand and staple fibers are obtained from crop or wild plants 
directly after a water retting process. Pulp fibers are usually obtained as individual cells from wood and sometimes plant sources (like sisal, banana, fique, and cotton linters) by a pulping process. Pulping is an extensive treatment with solutions that remove the lignin between cells and result in individual plant cells that are just a few $\mathrm{mm}$ long (Ardanuy et al. 2015; Elhawary 2015).

\section{Cellulose filaments}

Cellulose nanofibers can be assembled into filament form by wet-extrusion (Walther et al. 2011), flowfocusing (Håkansson et al. 2014), or spinning (Iwamoto et al. 2011; Vuoriluoto et al. 2017) processes. These cellulose filaments may have different physicochemical aspects (e.g. allomorph, crystallinity), but all filaments are mechanically strong, ductile, and have very high aspect ratios (Fig. 6). Filaments are interesting as building blocks of materials for biomedical applications.

There is also a different type of cellulose filament, which is not obtained via the above-described processes but by peeling cellulose fibers from wood or plants (Tibolla et al. 2017). This peeling process is only mechanical and does not require chemicals or enzymes and has no released effluent, which makes the generated filaments appealing for biomedical applications.

\section{Cellulose micro/nanofibrils}

Cellulose microfibrils, also originally-called microfibrillated cellulose (MFC), have been developed first by Turbak et al. (Turbak et al. 1983) and Herrick et al. (Herrick et al. 1983) at ITT Rayonier Inc., USA, in the late 1970s. Cellulose fibers (mainly from wood) are mechanically disintegrated into micro- and nanofibrils, for example by passing through a homogenizer. Cellulose nanofibrils (CNFs; width $<100 \mathrm{~nm}$ ) are mainly obtained at a low concentration from water suspensions of wood or plant pulps. CNFs are not always obtained as pure cellulose nanofibers; they can be disintegrated from sources that are still containing a considerable amount of hemicellulose and lignin (Abe et al. 2009; Kumagai and Endo 2018; Oliaei et al. 2020). Many attempts have been made to obtain individual fibrils, such as mechanical disintegration, including homogenization (Turbak et al. 1983; Wang et al. 2013) and micro-fluidization (Ferrer et al. 2012), as well as the application of enzymatic treatments (Tibolla et al. 2017; Wågberg et al. 2008). Some chemical treatments are also used to facilitate the disintegration of CNFs, such as TEMPO $(2,2,6,6$ tetramethylpiperidinyloxyl)-catalyzed oxidation (Isogai et al. 2011), and carboxymethylation (Wågberg et al. 2008), which also introduce different functionalities to the cellulose fibrils. The width of CNFs is generally in the range of 2-100 $\mathrm{nm}$ depending on the source of cellulose, fibrillation process, and pretreatment (Table 3). The length of CNFs is typically $>1 \mu \mathrm{m}$ (Dufresne 2013; Gumrah Dumanli 2017) (Table 3). CNFs are mostly comprised of alternating crystalline and disordered domains (Klemm et al. 2011). Principally, CNFs have typically an elastic modulus between 14 and $36 \mathrm{GPa}$ (Lindström 2017; Supachok et al. 2012), and an ultimate tensile strength around $1 \mathrm{GPa}$ (Ali and Gibson 2012; Lindström 2017) at ambient conditions, but even higher values have been reported (Bledzki and Gassan 1999; Henriksson et al. 2007; Sakurada et al. 1962).

\section{Crystalline cellulose}

When cellulose microfibrils are subjected to a proper combination of mechanical, chemical, and/or enzymatic treatments, the highly crystalline regions of the cellulose microfibrils can be extracted, resulting in the formation of microcrystalline cellulose (MCC; with a diameter in micron scale) or cellulose nanocrystals (CNCs; with a diameter in nano scale) (Trache et al. 2017). MCC and CNCs are stiff rodlike particles consisting of cellulose chain segments in a nearly perfect crystalline structure, which was first developed by Ranby (1949). MCC was first commercialized under the brand name Avicel ${ }^{\circledR}$ (Battista and Smith 1962). In 1964, the Food Machinery Corporation introduced Avicel ${ }^{\circledR} \mathrm{PH}$ to the pharmaceutical industry as an ingredient for direct tableting (Dinand et al. 1996). The length of MCC from Avicel ${ }^{\circledR} \mathrm{PH}$ is in the range of micrometers. Nowadays, MCC is produced by more than ten suppliers all around the world. The most common source of pharmaceutical MCC is wood cellulose (Thoorens et al. 2014). 
MCC is a purified form of partially depolymerized alpha cellulose through hydrochloric acid hydrolysis (Schuh et al. 2013). The partial depolymerization of the disordered regions of cellulose by acid hydrolysis produces shorter and more crystalline particles like MCC due to its inclination to hydrolysis (Wardhono et al. 2020; Zhao et al. 2015a). MCC has broad compatibility with active pharmaceutical ingredients (APIs), due to its physiological inertness, ease of handling, biodegradability, as well as inherent security of supply (Nsor-Atindana et al. 2017). Commercial MCC has round or rod-like particles measuring 10-200 $\mu \mathrm{m}$ (Juban et al. 2015). Pharmaceutical MCC is produced from softwood, hardwood (Thoorens et al. 2014), and cotton (Shlieout et al. 2002; Suzuki and Nakagami 1999). MCC has several advantages, such as biodegradability, thermal stability, satisfying mechanical characteristics, high elastic modulus, high aspect ratio, and low density, making it an appropriate candidate to be used as a filler in biocomposites (Pei et al. 2010). Moreover, the large surface area and high internal porosity of MCC provide appropriate cohesiveness for wetted mass (Zolkefpeli and Wong 2013).

$\mathrm{CNC}$ particles are the extracted crystalline regions of the cellulose microfibrils (Moon et al. 2011; Shopsowitz et al. 2010; Siqueira et al. 2010). Purified CNCs are often made by sulfuric acid hydrolysis of native cellulose. Aggressive sulfuric acid hydrolysis and ultrasonic treatment of bulk cellulose results in disintegration of highly crystalline CNC particles, which are then extracted. CNCs exhibit exceptional characteristics, such as a high aspect ratio, large specific surface area, high specific strength and modulus, along with abundance, biodegradability, reactive surfaces, and the ability to make stable suspensions in various low-polarity solvents when a surfactant is used (Chang et al. 2009; Wu et al. 2010). The characteristics of nanocrystals, e.g. shape, length, and width, depend on the cellulose source and the extraction procedure, e.g. controlled time and temperature for acid hydrolysis, high-pressure homogenization conditions ( $\mathrm{Lu}$ and Hsieh 2010) (Table 3), and further modifications, such as neutralization and dialysis (Martínez-Sanz et al. 2011).

CNCs can be prepared from different sources, including WC, PC, BC, algal, and tunicate cellulose (Le Goff et al. 2015; Martínez-Sanz et al. 2011; Siqueira et al. 2010). CNC particles can be isolated by breaking down MCC particles. After treatment of MCC particles with sulfuric acid, a stable dispersion of CNCs in water or organic solvents is prepared (Klemm et al. 2011). CNCs typically have a relatively broad length distribution because of the diffusion-controlled nature of the acid hydrolysis. Generally, the average length is a few hundred nanometers, and the width a few nanometers (Moon et al. 2011), with an aspect ratio between 10 for cotton (Ebeling et al. 1999), and 67 for tunicin (Angles and Dufresne 2000) and Capim dourado (golden grass) (Siqueira et al. 2010). Typically, CNCs derived from $\mathrm{WC}$ and $\mathrm{PC}$ have a length between $100-500 \mathrm{~nm}$, and a width between 3-30 nm, while tunicate- and bacteria-based cellulose have a length of $100 \mathrm{~nm}$ to several microns, and a width of 5-50 nm (Table 3). The degree of polymerization of cellulose in CNCs is in the range of 500 to 15000 . $\mathrm{CNC}$ has been reported to have an elastic modulus of 60-220 GPa, and a tensile strength of 7500$7700 \mathrm{MPa}$ (Table 4). Compared to bulk cellulose, which has more significant disordered fractions, these nanocrystals exhibit very high specific strength, elastic moduli, high surface area, and unique liquid crystalline properties (Wu et al. 2013).

$\mathrm{CNC}$ as nanoparticle reinforcement has received much attention as it has attractive advantages, such as low density, very good uniformity and durability, and biodegradability. The high strength and elastic modulus, as well as the small dimensions of nanocrystalline cellulose, provide a far-reaching reinforcement effect on the overall matrix structure (Le Goff et al. 2015; Septevani et al. 2018). The versatility and adaptability of bionanocomposites enable these nanocrystalline cellulose-based materials to be utilized for biomedical applications, including medical implants, wound dressing, drug delivery, and scaffolds for tissue engineering and vascular grafts (Rudisill et al. 2015).

\section{Cellulose properties}

Cellulose solubility

A major limitation of cellulose in biomedical applications is its insolubility in water and other common solvents. This is due to the stabilization of cellulose molecules by intra- and intermolecular hydrogen 
Table 4 Typical elastic modulus, tensile strength, and elongation to rupture of common cellulosic particle types

\begin{tabular}{|c|c|c|c|c|}
\hline $\begin{array}{l}\text { Cellulosic } \\
\text { particle types }\end{array}$ & $\begin{array}{l}\text { Elastic } \\
\text { modulus } \\
(\mathrm{GPa})\end{array}$ & $\begin{array}{l}\text { Tensile } \\
\text { strength } \\
(\mathrm{MPa})\end{array}$ & $\begin{array}{l}\text { Elongation to } \\
\text { rupture }(\%)\end{array}$ & $\begin{array}{l}\text { Reference(s) } \\
\text { (Measurement or estimation techniques) }\end{array}$ \\
\hline Plant fiber & $5-130$ & $300-1050$ & $1-8$ & $\begin{array}{l}\text { Bledzki and Gassan (1999), López et al. (2012, 2013), Moon et al. (2011) } \\
\text { (Tensile) }\end{array}$ \\
\hline $\begin{array}{l}\text { Wood pulp } \\
\text { fiber }\end{array}$ & $14-40$ & $380-1240$ & $3-22$ & $\begin{array}{l}\text { Bledzki and Gassan (1999), López et al. (2011), Moon et al. (2011), Mott } \\
\text { et al. (2002) (Tensile and micro-mechanical modelling) }\end{array}$ \\
\hline Wood CNF & $14-84$ & $1000-1300$ & $4-8$ & $\begin{array}{l}\text { Ali and Gibson (2012), Benitez and Walther (2017), Cheng et al. (2009), } \\
\text { Klemm et al. (2018), Lindström (2017), Supachok et al. (2012) } \\
\text { (Molecular modelling, micromechanical modelling, AFM and Raman) }\end{array}$ \\
\hline $\mathrm{BC}$ & $60-115$ & - & - & Guhados et al. (2005), Moon et al. (2011) (AFM and Raman technique) \\
\hline $\begin{array}{l}\text { Tunicate } \\
\text { cellulose }\end{array}$ & $110-200$ & - & - & Iwamoto et al. (2009) (AFM) \\
\hline $\mathrm{CNC}$ & $60-220$ & $7500-7700$ & - & $\begin{array}{l}\text { Dufresne (2017), Moon et al. (2011), Ramezani and Golchinfar (2019), } \\
\text { Rusli and Eichhorn (2008), Sturcová et al. (2005), Tashiro and } \\
\text { Kobayashi (1991) (Raman, Modeling, Inelastic X-ray scattering) }\end{array}$ \\
\hline
\end{tabular}

bonds, as well as to electrostatics and hydrophobic interactions within the integrated fibrils, forming tough bundles with numerous hydroxyl groups, which are distributed on the backbone (Bergenstråhle et al. 2010; Lindman et al. 2017). The overall effects of the hydrogen bonding mechanism on stabilization are not completely understood; recently, electrostatics, and hydrophobic interactions have been suggested to play an important role (Lindman et al. 2017). As a result of the consequent tight connections between the entangled chains of cellulose, cellulose becomes insoluble in water and most common solvents. Therefore, it is essential to develop intricate solvents that create systems requiring minimum energy for dissolving cellulose. Ionic liquids are considered environmentally friendly solvents, and some of them dissolve cellulose. Besides, ionic liquids have low toxicity, thermal stability, negligible volatility, recyclability, and promote dissolvability for cellulosic particles ( $\mathrm{Li}$ et al. 2016b). Ionic liquids, including 1-butyl-3-methylimidazolium formate (BMIMFmO) (Xu et al. 2010), 1-butyl-3-methylimidazolium chloride $(\mathrm{BmimCl})$ (Erdmenger et al. 2007), N,Ndimethylacetamide/lithium chloride (DMAc/LiCl) (Potthast et al. 2002), NaOH/thiourea (Jiang et al. 2017), LiOH/urea, and $\mathrm{NaOH}$-urea (Cai and Zhang 2005) are able to properly dissolve cellulose. 1-Ethyl3-methylimidazolium diethyl phosphate ([EMIM] DEP), an ionic liquid solvent, is a favorable cellulose solvent since it has low viscosity with a corresponding low melting point $\left(19-21{ }^{\circ} \mathrm{C}\right)$. A solution of cellulose in [EMIM] DEP-pyridine mixture is stable in time (Vitz et al. 2009).

Some ionic liquids can be used to dissolve cellulosic materials, but limitations exist regarding their usage such as high energy consumption, high cost, and inherent difficulty in solvent recovery (de Oliveira Ribeiro et al. 2018; Zhu et al. 2018a). $\mathrm{N}$-methylmorpholine-N-oxide monohydrate (NMMO-H2O), an organic solvent, has also been used to dissolve cellulose. NMMO is a nontoxic solvent, of which more than $99 \%$ can be recycled after dissolution (Zhang et al. 2017). Thus, depending on the specific conditions required for application, there is continuous interest in developing innovative cellulose solvents with favorable properties to allow usage of cellulose in biomedical applications.

\section{Mechanical properties of cellulose}

Cellulose-based materials and their composites with inorganic materials and polymers are emerging for the design of high-performance mechanical and functional materials (Benitez and Walther 2017). The high intrinsic stiffness and strength of cellulose I crystals yield promising materials that exhibit extraordinary mechanical properties if they are assembled correctly, making them a suitable candidate for biomedical applications where high mechanical performance is desired. CNFs, for 
instance, feature outstanding intrinsic mechanical properties (high specific modulus and strength) due to high crystallinity (Benitez and Walther 2017), as well as order and intermolecular interactions such as hydrogen bonding between cellulose chains (Yu et al. 2012). The elastic modulus of crystalline cellulose I along the cellulose chain axis has been reported to be 124-155 GPa (Šturcová et al. 2005; Tanaka and Iwata 2006; Tashiro and Kobayashi 1991).

The rigid crystalline CNCs have specific moduli similar to Kevlar and steel (Eichhorn et al. 2010; Moon et al. 2011; Xiong et al. 2016). Moreover, BC in never-dried form has exceptional mechanical characteristics that resemble soft tissue ( $\mathrm{Hu}$ and Catchmark 2011; Svensson et al. 2005). BC in the dried form also possesses exceptional mechanical properties. The elastic modulus of $\mathrm{BC}$ has been reported to be very high, i.e. 60-115 GPa (Benitez and Walther 2017; Guhados et al. 2005; Hsieh et al. 2008) (Table 4). The mechanical properties of BC and interactions with smooth muscle cells have been investigated, and it has been argued that the morphology of single nanofibrils, the network structures of $\mathrm{BC}$, and the stress-strain response reveal similarities to that of a collagen network (Bäckdahl et al. 2006). It is worth mentioning that extensive research has been carried out to improve collagen-based constructs (Berglund et al. 2003; L'Heureux et al. 1993; Seliktar et al. 2000), as they have enormous potential for biomedical applications. This opens up opportunities for novel biomimetic scaffold design where BC replaces the collagen network of the extracellular matrix. Information about the mechanical properties of cellulosic forms from different sources is provided in Table 4. Based on the data in Table 4, and what has been discussed so far, it can be easily understood that the elastic modulus and tensile strength of cellulosic reinforcements are very impressive and promising for biomedical applications such as tissue engineering, wound healing, and drug delivery, where strong and stable structures are required.

\section{Hygroscopic properties of cellulose}

Despite impressive mechanical properties of cellulose in dry-state, the low wet-strength of this material is a limiting parameter for many applications
(Mertaniemi et al. 2016). The reason for this problem is associated with the intrinsic hygroscopic properties of cellulose, which is considered a hygroscopic substance due to the tendency to form hydrogen bonding with water. The water molecules attract and hold in the structure of cellulose. Penetration of water in the structure of cellulose is mainly limited to the disordered domains. As a result, the percentage of disordered domains and fiber saturation point concur around 30\% (Kolin and Janezic 1996). The water swelling of cellulose allows for favorable aqueous processing of cellulose and/or cellulose-based hybrid and composite materials. However, such materials as products are prone to significant swelling due to both adsorption of moist air or absorption of liquid water along the hydrophilic surface of the cellulose or within embedded hydrophilic polymers. Nanocellulose-based materials can thus take up water and swell much more compared with fiber-based materials due to their higher surface area (Benítez et al. 2013). Moreover, in chemically modified cellulose-based materials that carry charged groups, water uptake is elaborated by the osmotic swelling pressure generated by the charged groups (Walther et al. 2020). These hygroscopic properties of cellulose might determine whether cellulose can be used for a specific biomedical application.

\section{Toxicity}

Toxicity of materials is a concern for biomedical applications. Cellulosic particles are extracted from sources with no or low toxicity, but the dimension, surface modification, hydrophilization, hydrophobization, and aggregation might influence their cytotoxicity and biocompatibility. Generally, the nanoscale dimension of particles has been recognized as a potential factor generating toxicity of materials that are composed by these particles (Nel et al. 2006). Conflicting reports on in vitro research exist on cyto-, geno-, and immunotoxicity of cellulosic nanoparticles (Catalán et al. 2015; Coelho et al. 2018). Moreover, inflammation is often occurring after exposure to cellulosic nanoparticles as a normal biological response to a foreign material. It may disappear after a while. Attempts have been made to correlate the cellulosic nanoparticle size and rigidity (of a specific type and chemical function) to cell toxicity in acute tests, but no clear correlation has 
been documented. Therefore, more research is needed on the long-term in vivo effects of cellulose nanomaterials, since this may provide different results from those obtained by acute and in vitro studies.

\section{Cellulose derivatives}

For upgrading the value or expanding versatility of cellulose, and by using chemical treatment or functionalization, various cellulose derivatives have been developed and utilized in biomedical industries. The properties of cellulose derivatives are not only determined by the type and degree of substitution, but also by the functionalization pattern along the polymer chain. Regio-selective synthesis of cellulose derivatives is limited by cellulose' poor solubility in organic solvents, and high steric hindrance due to the stiff and bulky cellulose main chain. The hydroxyl group is the most targeted reactive group on the cellulose chain. Cellulose hydroxyl groups are relatively poor nucleophiles, resulting in the requirement for fairly harsh reactions, so that taking advantage of the relatively small reactivity differences between the 2-, 3- and 6-OH groups is difficult (Zheng et al. 2014). Therefore, regio-selective substitution is one of the remaining challenges in the synthesis of cellulose derivatives. To synthesize cellulose derivatives under more general and practical conditions for commercial purposes, it is necessary to understand the relationship between cellulose derivatives' regiochemical structure and their properties (Zheng et al. 2014). The chemical derivatization of cellulose, based on the hydroxyl group, generally includes etherification and esterification. The derivatives may vary in terms of essential characteristics, e.g. chemical structure, moisture sorption, water interaction, surface activity, and solubility, which is discussed below in detail, and summarized in Table 5 .

\section{Cellulose ether}

Cellulose hydroxyl groups can be partially or totally etherified by different reagents, e.g. epoxides, alpha halogenated carboxylic acids, and halogenoalkanes (Kamel et al. 2008). The solubility rate of cellulose ethers (CEs) is affected by the acidity or alkalinity of the solution. In acidic conditions, cellulose ether dissolves very slowly, while in alkaline conditions it dissolves rapidly. Cellulose ether can be watersoluble depending on the substituent chemical structure, as well as degree and pattern of substitution. Most water-soluble cellulose ethers have a degree of substitution of 0.4-2. Although many cellulose ether compositions have been synthesized since the early 1900 s, only a few have gained commercial importance. Among all CEs, carboxymethyl cellulose (CMC), methyl cellulose, and hydroxyethyl cellulose are extensively used in the formulation of industrial biomedical products due to their nontoxic profile and appropriate rheological and mechanical properties. CEs high water retention capacity (Fidale et al. 2013) and thermo-gelling ability (Sanz et al. 2015) are known to accelerate wound healing. These important properties of CEs depend on the chemical structure of the substituent and degree of substitution. Despite the success of hydrated CEs in practical biomedical applications, rather few attempts have been made to investigate CEs water retention mechanism.

\section{Methyl cellulose}

Methyl cellulose is the most important commercial cellulose ether. Methyl cellulose is the simplest alkyl ether, which can be synthesized in an alkaline medium with a methylating agent, such as methyl chloride or dimethyl sulfate (Viera et al. 2007) (Fig. 7). A different degree of substitution can be obtained via altering the synthesis conditions, such as the reaction time or the methylating agent (Viera et al. 2007). Methyl cellulose dissolves in many organic solvents, depending on the degree of substitution. For instance, if the degree of substitution is between 1.4 and 2.0, methyl cellulose dissolves in water, and if this degree is between 2.4 and 2.8, it is generally soluble in water and some organic solvents (Table 5) (Vieira et al. 2012). Methyl cellulose has thermo-gelling ability. The degree of cellulose substitution, molecular weight, presence and concentration of additives are parameters affecting the methyl cellulose gel-formation temperature and the characteristics of the resulting gel (Sarkar 1979). Besides, methyl cellulose is an emulsifying additive (Içten et al. 2017), which is useful for drug delivery systems. Methyl cellulose is mostly used for biomedical applications such as tissue engineering, wound healing, and pharmaceutical formulations. 
Table 5 Chemical structure, specific functional group, major solvents, and applications of cellulose derivatives

\begin{tabular}{|c|c|c|c|c|c|}
\hline $\begin{array}{l}\text { Cellulose } \\
\text { derivatives }\end{array}$ & Type & $\begin{array}{l}\text { Specific } \\
\text { functional } \\
\text { group }\end{array}$ & Solvent & Major applications & Reference(s) \\
\hline \multirow[t]{5}{*}{$\begin{array}{l}\text { Cellulose } \\
\text { ether }\end{array}$} & $\begin{array}{l}\text { Methyl } \\
\text { cellulose }\end{array}$ & $-\mathrm{OH}$ or $-\mathrm{OCH}_{3}$ & $\begin{array}{l}\text { Cold water }\left(<50^{\circ} \mathrm{C}\right) \text {, } \\
\text { acetic acid }\end{array}$ & $\begin{array}{l}\text { Food industry, tissue } \\
\text { engineering }\end{array}$ & $\begin{array}{l}\text { de Dicastillo et al. (2016), } \\
\text { Nasatto et al. (2015), } \\
\text { Schütz et al. (2017) }\end{array}$ \\
\hline & $\mathrm{CMC}$ & $\begin{array}{l}-\mathrm{OH} \text { or } \\
-\mathrm{OCH}_{2} \mathrm{COOH}\end{array}$ & Water & $\begin{array}{l}\text { Tissue engineering, wound } \\
\text { dressing, drug } \\
\text { delivery, food industry, } \\
\text { adsorption technologies, } \\
\text { water-based paints, } \\
\text { textile, paper industry }\end{array}$ & $\begin{array}{l}\text { Capanema et al. (2018), } \\
\text { Duan et al. (2016), } \\
\text { Mondal et al. (2015), } \\
\text { Mousavi et al. (2017), } \\
\text { Ogushi et al. (2007) }\end{array}$ \\
\hline & Ethyl cellulose & $\begin{array}{l}-\mathrm{OH} \text { or }- \\
\mathrm{OCH}_{2} \mathrm{CH}_{3}\end{array}$ & $\begin{array}{l}\text { Glycerol, propane-1,2- } \\
\text { diol, } \mathrm{H}_{2} \mathrm{O} \text {-insoluble }\end{array}$ & $\begin{array}{l}\text { Paper industry, tissue } \\
\text { engineering }\end{array}$ & $\begin{array}{l}\text { Hakulinen (1988), Wang } \\
\quad \text { et al. (2017) }\end{array}$ \\
\hline & $\begin{array}{l}\text { Hydroxy-ethyl } \\
\text { cellulose }\end{array}$ & $\begin{array}{l}-\mathrm{OH} \text { or } \\
-\mathrm{OCH}_{2} \mathrm{CH}_{2} \mathrm{OH}\end{array}$ & Water & $\begin{array}{l}\text { Cosmetic, cleaning } \\
\text { solutions }\end{array}$ & $\begin{array}{l}\text { Durand-Cavagna et al. } \\
\text { (1989), Kozlowska et al. } \\
\text { (2018) }\end{array}$ \\
\hline & $\begin{array}{l}\text { Hydroxy- } \\
\text { propyl } \\
\text { cellulose }\end{array}$ & $\begin{array}{l}-\mathrm{OH} \text { or } \\
-\mathrm{OCH}_{2} \mathrm{CH} \\
(\mathrm{OH}) \mathrm{CH}_{3}\end{array}$ & Water & $\begin{array}{l}\text { Tissue engineering, drug } \\
\text { delivery, wound healing, } \\
\text { sensor technologies }\end{array}$ & $\begin{array}{l}\text { Li et al. (2019b), Yamada } \\
\text { et al. (1999), Zhang et al. } \\
\text { (2019) }\end{array}$ \\
\hline \multirow[t]{3}{*}{$\begin{array}{l}\text { Cellulose } \\
\text { ester }\end{array}$} & $\begin{array}{r}\text { Cellulose } \\
\text { acetate }\end{array}$ & $\begin{array}{l}-\mathrm{OH} \text { or } \\
-\mathrm{O}(\mathrm{C}=\mathrm{O}) \mathrm{CH}_{3}\end{array}$ & $\begin{array}{l}\text { Acetone, acetic acid, } \\
\text { dimethylacetamide }\end{array}$ & $\begin{array}{l}\text { Separation industry, textile, } \\
\text { tissue engineering, } \\
\text { wound healing, drug } \\
\text { delivery, food packaging }\end{array}$ & $\begin{array}{l}\text { Dairi et al. (2019), Ioniță } \\
\text { et al. (2018), Liakos et al. } \\
\text { (2018) }\end{array}$ \\
\hline & $\begin{array}{l}\text { Cellulose } \\
\text { nitrate }\end{array}$ & $\begin{array}{c}-\mathrm{OH} \text { or }- \\
\mathrm{ONO}_{2}\end{array}$ & $\begin{array}{l}\text { Methanol, nitrobenzene, } \\
\text { mixture of ethanol- } \\
\text { ether }\end{array}$ & $\begin{array}{l}\text { Separation industry, } \\
\text { painting, coating, } \\
\text { explosive materials }\end{array}$ & $\begin{array}{l}\text { Maynard (1848), } \\
\text { Schoenbein (1849), } \\
\text { Shashoua et al. (1992), } \\
\text { Soylak et al. (2002 }\end{array}$ \\
\hline & $\begin{array}{l}\text { Cellulose } \\
\text { sulfate }\end{array}$ & $\begin{array}{r}-\mathrm{OH} \text { or }- \\
\mathrm{OSO}_{3} \mathrm{H}\end{array}$ & Water & $\begin{array}{l}\text { Tissue engineering, drug } \\
\text { delivery, cell } \\
\text { immobilization/ } \\
\text { encapsulation }\end{array}$ & $\begin{array}{l}\text { Palaninathan et al. (2018), } \\
\text { Su et al. (2019) }\end{array}$ \\
\hline
\end{tabular}

CMC carboxymethyl cellulose

\section{Carboxymethyl cellulose}

CMC is one type of CEs, which is commercially available and has unique features like hydrophilicity, water solubility and stability, high chemical stability, nontoxicity, biocompatibility, and biodegradability. Also, it has no known side effects to human health (Sahoo and Jena 2018). However, it is insoluble in some organic solvents such as ethanol. The solubility of CMC depends on the degree of polymerization, the degree of substitution, and on the distribution of the substituent. CMC can be used as effective viscosity increasing agent, rheological control agent, binder, stabilizer, and film former in the biomedical field with particular attention to drug delivery and tissue engineering systems. CMC is formed by reaction of cellulose with monochloroacetic acid, where the hydroxyl groups are substituted by carboxymethyl groups in $\mathrm{C} 2, \mathrm{C} 3$, and $\mathrm{C} 6$ of each glucose residue, such that the substitution slightly prevails at the $\mathrm{C} 2$ position. No secondary $\mathrm{OH}$ groups are formed during the reaction (Heinze and Pfeiffer 1999; Xiquan et al. 1990). Therefore, CMC chemical structure is based on carboxymethyl groups $\left(-\mathrm{CH}_{2}-\mathrm{COOH}\right)$ bound to some of the hydroxyl groups of the cellulose backbone (Fig. 7) (Swamy and Yun 2015). The degree of substitution of commercial CMC grades for biomedical products is typically between 0.6 and 1.25 (Swamy and Yun 2015). CMC properties depend on its molecular weight, degree of substitution, and the 


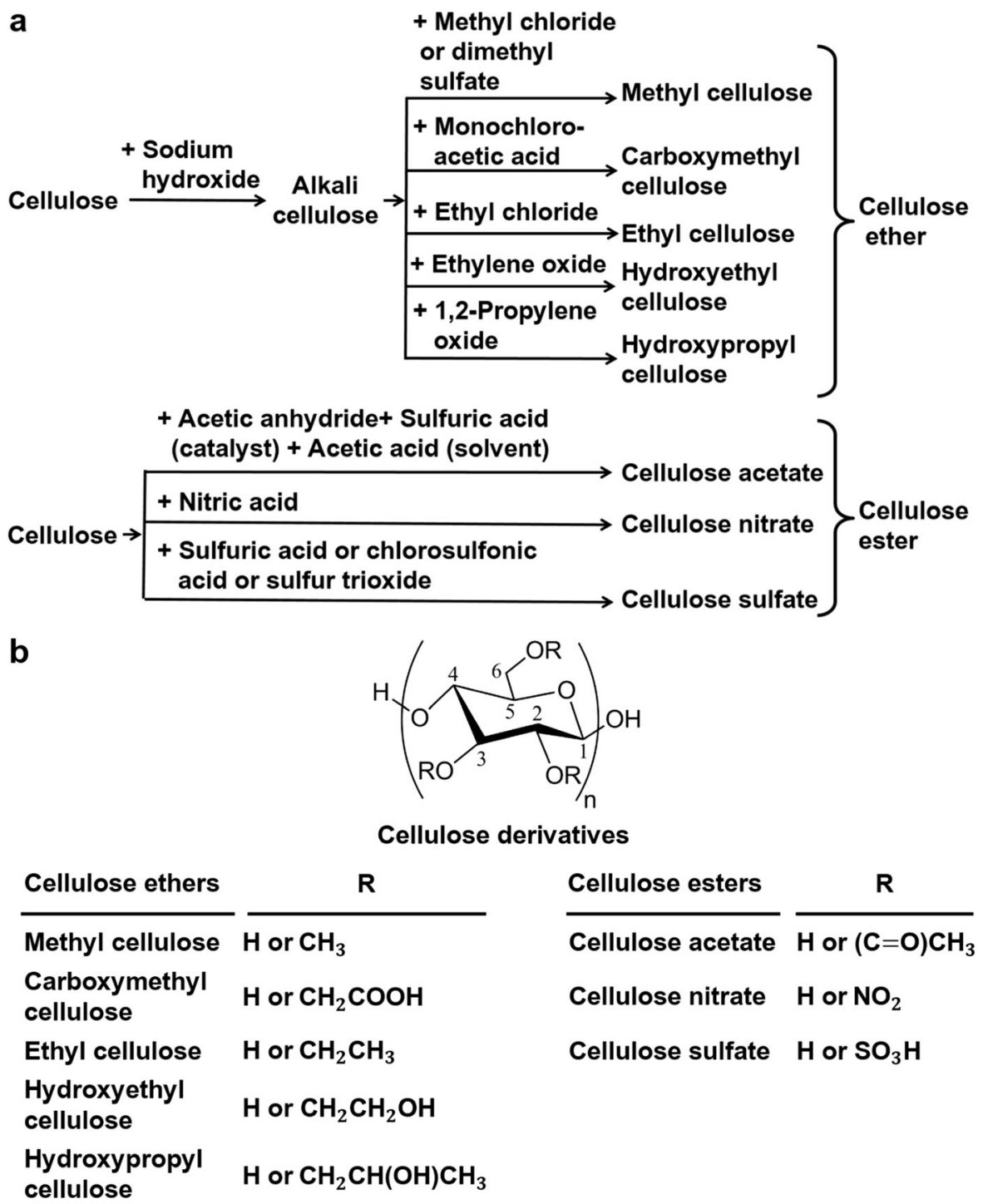

Fig. 7 Classification of cellulose derivatives. a Chemical conversion procedures of cellulose to its derivatives. b Chemical structure of cellulose derivatives

distribution of carboxymethyl substituents along the polymer chains. CMC is often activated in aqueous sodium hydroxide, whereby it is transformed into its sodium form for further use.

\section{Ethyl cellulose}

Ethyl cellulose is another important commercial CE. The chemical structure of ethyl cellulose is based on converting some of the hydroxyl groups on the repeating glucose units into ethyl ether groups (Fig. 7) (Davidovich-Pinhas et al. 2015). Ethyl cellulose is prepared by reaction of alkali cellulose with ethyl chloride at about $60{ }^{\circ} \mathrm{C}$ for several hours (Rekhi and Jambhekar 1995). The complete etherification of cellulose yields triethyl cellulose, although normally ethyl cellulose with 2-2.6 degree of substitution is used for a range of commercial products (Koch 1937). The physical characteristic and performance of materials based on ethyl cellulose depend on the degree of etherification, molecular weight, and molecular uniformity. Solubility in most organic solvents is typically achieved with degree of substitution between 2.2 and 2.6 (Koch 1937). 
Ethyl cellulose is a biodegradable substance that has no water-solubility, no toxicity, excellent filmforming capacity, water resistance, and barrier-forming characteristics (Yang et al. 2014). Ethyl cellulose has excellent strength at room temperature, but its strength decreases immediately with increasing temperature. Ethyl cellulose has potential for use in biomedical applications, especially drug delivery.

\section{Hydroxyethyl cellulose}

Another CE is hydroxyethyl cellulose, which is prepared from the reaction of alkali cellulose and ethylene oxide (Wang et al. 2015) (Fig. 7). The chemical structure of hydroxyethyl cellulose can be easily further modified due to its reactive hydroxyl groups. Hydroxyethyl cellulose is soluble in hot and cold water (Zhang and Chen 2002) and many organic solvents. Its ease of solubility makes it an appropriate candidate in many biomedical applications (Yang et al. 2016). Further, its non-toxic nature, ease of compression, ability to host nanoparticles, and capability to accommodate a high level of drug loading are critical factors for its biomedical usage (Yang et al. 2016). Also, hydroxyethyl cellulose can be mixed with cellulose, enabling solvent-free processing of cellulose, and making it more compatible with less-polar matrices (Hooshmand et al. 2017), which might further expand cellulose applications in the biomedical field.

\section{Hydroxypropyl cellulose}

Hydroxypropyl cellulose is a water-soluble (both in cold and hot medium) thermoplastic in the category of CEs. The chemical structure of hydroxypropyl cellulose is based on partial or complete substitution of free hydroxyls with hydroxypropyl groups. In the reaction with 1,2-propylene oxide, secondary $\mathrm{OH}$ groups are formed (Fig. 7). These secondary groups can further react. Therefore, the chemical structure of hydroxypropyl cellulose can be easily further modified due to its backbone reactive hydroxyl groups, which may provide new properties that are of interest for biomedical applications e.g. drug delivery and tissue engineering.
Cellulose ester

Cellulose ester is a commercially available class of thermoplastic biopolymers derived from cellulose (Moraïs et al. 2010). Unlike cellulose, cellulose esters have good solubility in common solvents and melt before decomposition (Edgar et al. 2001). Various morphological forms of cellulosic particles, e.g. fibers, fibrils, or crystals, can be esterified to form cellulose ester (Berlioz et al. 2009; Ramírez et al. 2017). Cellulose esters can be utilized in biomedical applications via less complicated production processes, which are further discussed below.

\section{Cellulose acetate}

Cellulose acetate (CA) was first discovered in 1865 by Schützenberger (Kulterer et al. 2011) as a thermoplastic biodegradable polymer. It is produced by the esterification of cellulosic sources such as cotton, wood, sugarcane, and even recycled paper (Rodrigues Filho et al. 2011). CA is relatively cheap since it is commonly obtained from agricultural byproducts, like cotton burrs, cottonseed hulls, and sugarcane bagasse (Cheng et al. 2010). Also, the existing CA preparation techniques do not need further chemical or mechanical treatment to isolate remaining cellulose from other components, which is advantageous for some biomedical applications, e.g. tissue engineering (Vikingsson et al. 2015), wound healing (Schunck et al. 2005), and drug delivery systems (Mwesigwa and Basit 2016).

Generally, CA synthesis approaches include ringopening esterification and transesterification under heterogeneous or homogeneous conditions (Khoshnevisan et al. 2018). CA is conventionally produced by acetylation of hydroxyl groups in cellulose with acetic anhydride (Clermont and Manery 1974), acetic acid (solvent), and sulfuric acid (catalyst) (Fig. 7).

$N$-ethyl-pyridinium chloride (Heinze et al. 2000), $\mathrm{N}, \mathrm{N}$-dimethylacetamide (DMAc)/lithium chloride (LiCl) (Morgado et al. 2013), and 1,3-dimethyl-2imidazolidinone (DMI)/LiCl dissolve CA (Chen et al. 2016a). These solvent systems typically need prolonged pretreatment. Ionic liquids have also been used as efficient solvents of CA (Abbott et al. 2005), though their industrial application is limited due to their high cost (Chen et al. 2016a). 
Cellulose nitrate

Cellulose nitrate, also known as nitrocellulose or celluloid, is considered the first semi-synthetic polymer in the advent of the plastic industry. Cellulose nitrate is a versatile polymer that has been widely used since the 1900s (Falkowitz and Piech 1956). Cellulose nitrate is commercially produced through the reaction of cellulose with nitric acid, by substituting cellulose hydroxyl groups with nitrate groups (Fig. 7). Cellulose nitrate is the polynitrate ester of cellulose with a typical 2.2-2.8 nitrate groups per glucose unit within the structure (Neves et al. 2019). Cellulose nitrate properties and applications depend on the degree of nitration. Cellulose nitrates are employed as explosives, plastics, or in coating and ink industries. By lowering the degree of nitration and adding a plasticizer, a workable plasticized material could be produced (Neves et al. 2019). Future studies may explore the possibilities of cellulose nitrate in biomedical applications.

\section{Cellulose sulfate}

Cellulose sulfate is a cellulose derivative with relatively simple chain structure and unique biological properties. The sulfation of cellulose is carried out using amongst others sulfuric acid, sulfur trioxide, and chlorosulfonic acid (Schweiger 1972). The reaction is carried out either directly on cellulose (under heterogeneous condition) or on partially substituted cellulose esters or ethers (mostly under homogeneous condition). Cellulose sulfate generally has water soluble, antiviral, antibacterial, and anticoagulant properties, which can be attributed to the presence of the sulfate groups and the broad degree of substitution. Apart from the simplicity in preparation, affordable cost, and large-scale production, cellulose sulfate's excellent biocompatibility, film-forming ability, and biodegradability makes it a frontrunner for potential biomedical applications like tissue engineering (Palaninathan et al. 2018) and drug delivery (Su et al. 2019).

\section{Cellulose in biomedical applications}

For biomedical applications, it is an essential requirement to assess the biocompatibility of materials and verify their interaction with cells, especially for applications where the material needs to remain in contact with living tissue and should not cause any cytotoxic or other side effects. Cellulose offers unique features of biodegradability, biocompatibility, low production cost as compared to synthetic biopolymers, abundance, sustainable resources, nontoxicity, and excellent mechanical properties. These features offer potential as bioresorbable polymers that plays an increasingly important role in biomedical applications due to their unique ability to be resorbed entirely in pre-designed time frames ranging from months to a few years.

\section{Tissue engineering}

Tissue engineering is known as an interdisciplinary field that applies the principles of engineering and life sciences toward the development of smart biological substitutes that potentially restore, maintain, and improve tissue functions that have malfunctioned (Table 6). The tissue engineering field generally utilizes biomaterials to develop constructs for intended medical interventions. Such constructs are to be exposed to living biological entities in the human body, from biomolecules and physiological fluids to cells, up to tissues and organs. In terms of physical properties, regenerative tissue material must possess optimal strength, e.g. compressive strength for bone tissue engineering, or tensile strength for artificial blood vessels and other soft tissue repairs. On the other hand, chemical considerations such as the surface chemistry of the materials are crucial, and the selection of materials must be rendered for specific application purposes. For instance, it is possible to tune porosity, thickness, and interconnectivity of nanocellulosic materials without compromising the mechanical properties for tissue scaffold production (Bäckdahl et al. 2008). For tissue engineering, cellulose as an additive or as primary scaffold material should have mechanical properties matching real tissues (Farzamfar et al. 2018; Hasan et al. 2018), promote porous structures for scaffolds (Hoo et al. 2013), or provide anchoring sites for osteoblasts (Gouma et al. 2012), and fibroblasts (Taokaew et al. 2015). The most commonly used cellulose derivatives for tissue engineering include cellulose acetate (Farzamfar et al. 2018), hydroxyethyl cellulose (Zulkifli et al. 2017), hydroxypropyl 


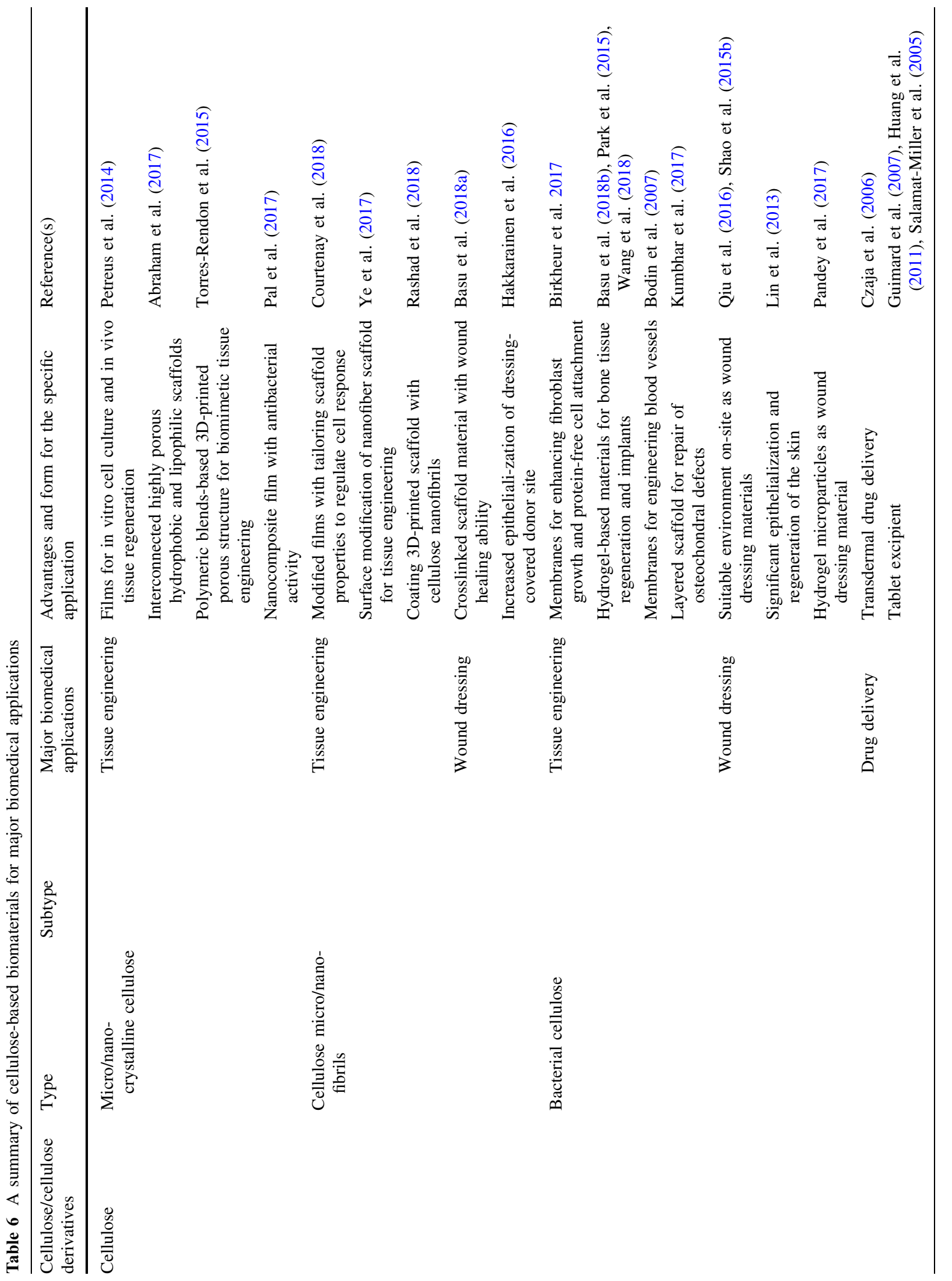









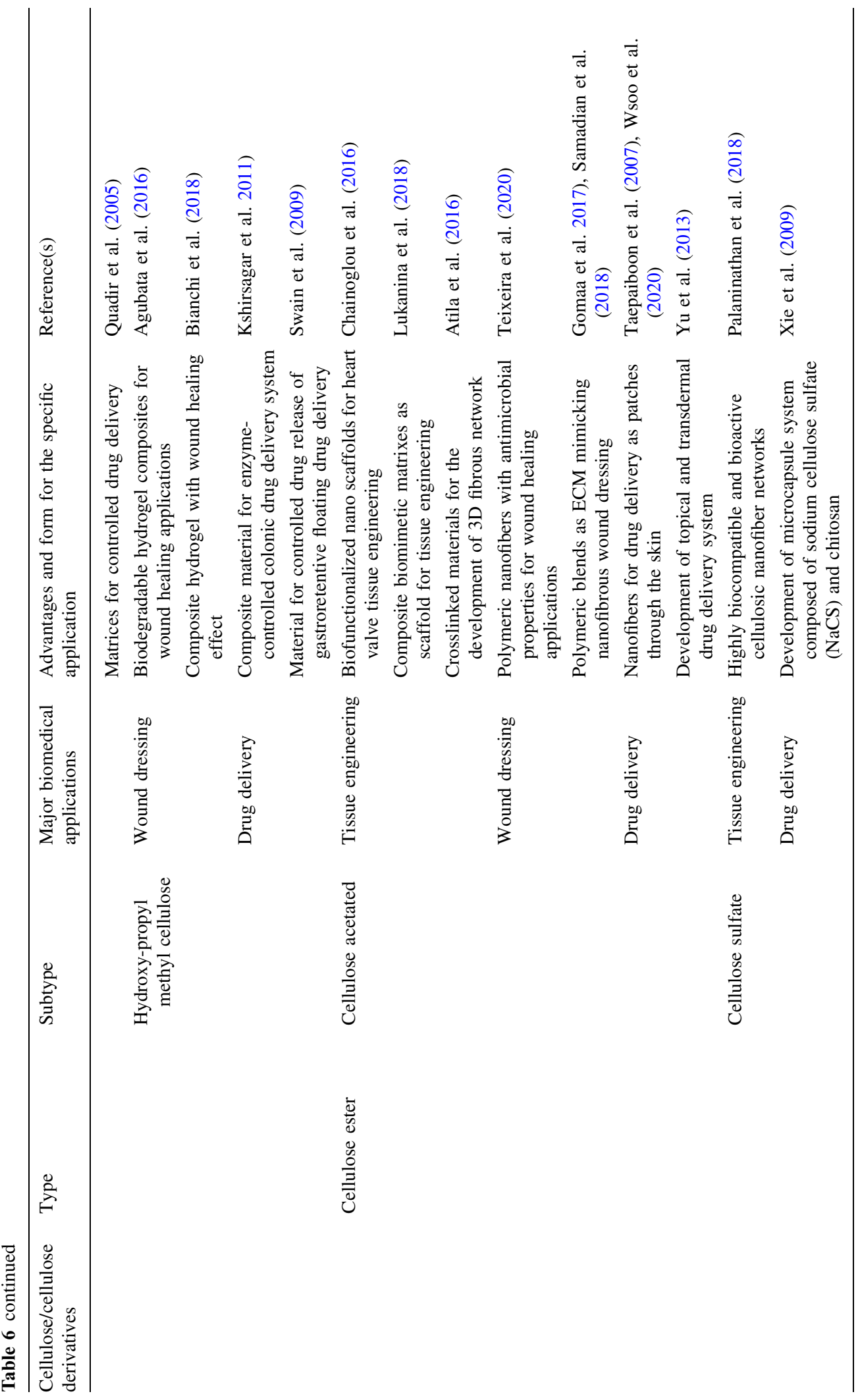


cellulose (Hoo et al. 2013), cellulose sulfate (Palaninathan et al. 2018), carboxymethyl cellulose (Hasan et al. 2018), methyl cellulose (Zhuo et al. 2017), and ethyl cellulose (Mao et al. 2018a).

One of the ubiquitous usages of biomaterials in tissue engineering is in the production of a biologically compatible scaffold that will support the attachment, proliferation, and differentiation of living cells that contribute to the promotion of tissue regeneration in vitro and in vivo conditions. Mammalian cells are not able to attach to the cellulosic surfaces used in artificial tissue scaffolds due to their hydrophilic nature and low non-specific protein adsorption. However, cell adhesion to substrate surfaces in cellulosic materials can be improved by the addition of matrix ligands. For example, ionic charges can be added to the cellulose membranes to adsorb collagen on the membrane surfaces, which can promote cellular adhesion (Courtenay et al. 2017). The positively charged BC has been applied, in the absence of proteins, to enhance cell attachment (Courtenay et al. 2017). BC is a biomaterial with a huge potential in dental and oral applications (CanasGutierrez et al. 2020). Recently, cost-effective and user-friendly functional biopolymeric-based materials have been used as a promising tool for developing, repairing, and regenerating functional tissues and organs in the human body. The use of cellulosic composites has been proposed in developing scaffold constructs that can be implanted in patients to replace failing or malfunctioning organs. Moreover, the inclusion of the appropriate reinforcement material for tissue-engineered biocomposite scaffolds is a significant factor in improving its characteristics and sustained biocompatibility. The use of cellulosic materials as reinforcement in biocomposites is now a fast-growing field, on account of their property enhancing capabilities (Ao et al. 2017; Sajjad et al. 2019). For instance, cellulosic fibers have been demonstrated recently to improve the formidability of biocomposite scaffolds in bone tissue engineering applications due to their unique structure (Mao et al. 2018b). In addition, microfibrillated cellulose remarkably increases the surface area, and its interfibrillar hydrogen bonds facilitate network formation, which is desirable in bone tissue engineering (Ioniță et al. 2018). Moreover, CMC stimulates adhesion, spreading, and migration of mouse fibroblasts in vitro (Adachi et al. 1992;
Aoshima and Jo 2013). Also, the presence of CMC decreases osteoclastogenesis by murine bone marrow progenitors (Agis et al. 2010), but increases osteoblast differentiation (Qi et al. 2018). Hydroxyethyl cellulose is a non-ionic, water-soluble polymer, and has a $\beta$-glucose linkage, which makes it a suitable candidate for tissue engineering applications. Hydroxyethyl cellulose increases cell viability and substantially stimulates cell growth (Tohamy et al. 2018). It also significantly enhances cell proliferation at high concentrations of hydroxyethyl cellulose (Chahal et al. 2016).

The appropriate mechanical properties of biomedical devices and materials are essential and very specific to the nature of the application area. For example, the elastic modulus of the material needs to be close to the medium and/or tissue that it is replacing or reinforcing. Nanocrystalline cellulose can be a promising material for cell attachment and proliferation due to its excellent mechanical properties and biocompatible nature. One particular advantage of using nanocrystalline cellulose is the fibrillar high aspect ratio building blocks, which construct a natural fiber network of fibrils or nanorods that is held together by hydrogen bonding and mechanical entanglement. Such a network could be even further reinforced mechanically by cross-linking the individual nanofibers. There are numerous cellular species cultured on nanocellulose biomaterials such as hydrogels, electrospun nanofibers, sponges, composites, and membranes (Luo et al. 2019). Among the sources of nanocellulose, bacterial nanocellulose is believed to be the most popular choice for cell culture due to its high porosity, biodegradability, and low toxicity (Halib et al. 2019). Usually, the rate of scaffold degradation under a given condition is an important issue as it should match the time of tissue formation to ensure the injured tissue is completely replaced by healthy tissue, and its function is restored.

\section{Wound dressing}

The wound healing process involves an elaborate series of biological phenomena to restore barrier functionality, prevent dehydration, and reduce the risk of bacterial infection. Burn wounds and skin grafting require the development of novel wound dressing materials. Cellulose-based polymers have a 
high potential for wound dressing applications (Table 6). As wound dressing material, they should promote water retention or high water absorption capacity (Wutticharoenmongkol et al. 2019) or promote porosity and dryness that abhors bacterial attachment (Henschen et al. 2016). Here, the cellulosic material must be shaped like a sheet and used as a cover on wounds. It is highly beneficial to make drug-loaded cellulose-based bandages (Fan et al. 2019). Nanocellulose has excellent potential for wound healing applications, based on its moisture absorption and water retention ability that can be implemented over the wound itself, to contribute towards lowering inflammatory responses and promoting fibroblast proliferation in the wound healing cascade (Wang et al. 2016). Nanofibrillar cellulose is an ideal matrix for wound healing due to its high surface area to volume ratio, high water-holding ability, and high porosity. Moreover, its structure allows to mimic the architecture of the extracellular matrix or tissue/organs. Nanofibrillar cellulose hydrogel is a novel material for controlling excessive wound contraction in vivo and in vitro (Nuutila et al. 2018). Nanofibrillar cellulosics such as CMC and CA are the most promising wound dressing cellulosic materials that have been used in the treatment of burns and ulcers due to biocompatibility with mucous membrane and skin, biodegradability, non-toxicity, low immunogenicity, high water bonding affinity, and swelling capacity (Gomaa et al. 2017; Hakkarainen et al. 2016). Oxidized cellulose nanofiber is also appropriate for wound healing applications because of its substantial water absorption capacity and well-dispersed cellulose fibrils (Shefa et al. 2017).

Using CMC in wound healing requires some modifications to decrease the consequent pain burden in patients. A low level of localized pain, postoperative bleeding, and synechia have been reported for dissolvable CMC foam dressing (Szczygielski et al. 2010). Dissolvable CMC foam can also be used as wound dressing after sinus surgery due to the observed low levels of postoperative bleeding and synechia formation during application (Szczygielski et al. 2010). Nanocomposites based on BC are prepared by the direct introduction of magnetic nanoparticles within the cellulose culture medium for efficient chronic wound healing. Bionanocomposites containing plant $\mathrm{CNC}$ have been reported to be suitable wound healing templates for accelerating tissue regeneration (Singla et al. 2017). CA is also a suitable candidate in biocomposites for wound healing scaffold upon developing electrospun nanofibers (Wutticharoenmongkol et al. 2019). Hydrophilicity and bioactivity of $\mathrm{CA}$ enables cellular interaction between $\mathrm{CA}$ and fibroblasts, which consequently promotes cell proliferation (Gomaa et al. 2017).

$\mathrm{BC}$ is an appealing candidate for wound healing applications based on its favorable characteristics, such as biocompatibility, nontoxicity, and mechanical stability. Furthermore, BC provides a moist environment for the wound, hence enhancing the healing process (Sulaeva et al. 2015; Zmejkoski et al. 2018). However, BCs provide a suitable environment on-site as wound dressing materials, but the $\mathrm{pH}$ conditions can affect their contribution to the healing process (Shao et al. 2015a). Different materials have been incorporated to develop BC-based biomaterials with enhanced properties to be suitable for wound dressing (Qiu et al. 2016). BC-montmorillonite-reinforced composites have been developed as wound dressing and regeneration materials for therapeutic applications without any side effects (Ul-Islam et al. 2013). BC-chitosan membranes show antibacterial activity and favorably low cytocompatibility for wound dressing (Lin et al. 2013). BC-based membranes show significant epithelialization and regeneration of the skin, faster than the commercial wound dressing product, Tegaderm ${ }^{\mathrm{TM}}$ (Lin et al. 2013). Besides, the $\mathrm{BC}$ membrane accelerates the wound healing process in a burn model system through the regulation of angiogenesis and connective tissue formation (Kwak et al. 2015). BC-based hydrogel microparticles have been used as a dressing material for coverage of partial-thickness burn wounds both in vitro and in vivo (Pandey et al. 2017). Oxidized BC is another kind of cellulosic materials, which is appropriate for wound healing since it possesses considerable water absorption capacity, antibacterial effect, and welldispersed cellulose fibrils (Wu et al. 2018).

\section{Drug delivery}

A drug delivery system is defined as the release of drugs at an appropriate time, to specifically targeted organs in a specified amount. Drug delivery systems transfer drugs to the desired organs, tissues, or cells, where the transfer mechanism can be controlled to 
respond to environmental stimuli such as light, temperature, $\mathrm{pH}$, chemical actions, and electric and magnetic fields. Cellulose has a long history of application in the pharmaceutical industry, where it has been used as a tablet-coating when blended with various excipients for oral administration. Despite an extended history of use in tableting, there is still ongoing research on the potential use of cellulose and its derivatives in advanced drug-loaded systems in terms of the rate of tablet dissolution as appropriate excipients or extended drug release as novel drug carriers (Table 6) (Abeer et al. 2014; Yan et al. 2019). As a drug delivery system, cellulosic materials should promote controllable diffusive properties and dissolvability. For instance, cellulose and its derivatives have been observed to exhibit definite drug delivery patterns by instant, controlled, or delayed-release in oral dosage forms (Godakanda et al. 2019; Jeddi and Mahkam 2019). Furthermore, the natural resistance of cellulosic materials to the acidic environment of the stomach makes them very practical to use as enteric coatings on capsules or tablets (Guo et al. 2002).

Extemporaneously, compounded medicines are used when a needed dose or dose form is commercially inaccessible, or when a particular dosing regime is required. Powdered cellulose and MCC are used as adsorbents, capsule diluents, and thickening stabilizing agents in compounded medicines (Marques-Marinho and Vianna-Soares 2013). MCC shows viscoelastic behavior and sensitivity to the strain rate. In high-speed tableting, the time for plastic deformation is limited, and hence, in this case, elastic effects are more significant (Roberts and Rowe 1985). Thus, in the formulation design and dosing, dependency of MCC to the strain rate should be considered (Thoorens et al. 2014).

CNFs possess a considerable potential in biomedicine as carrier for controlled drug delivery because of their suitable flexibility, conducive elasticity, low density, low toxicity, and relatively reactive surface, that can be used for grafting specific groups, in addition to being renewable and cheap. The rheological, barrier, and physicochemical characteristics of CNFs allow them to stabilize oil-water and air-water interfaces. Moreover, CNFs' high surface area per unit mass provides stabilization of nanoparticles and a higher probability for positive molecular interaction with poorly soluble drugs. CNFs have been used as stabilizers for crystalline drug nanoparticles, as matrix former to obtain a long-lasting sustained drug release over several weeks, and as film former with immediate release properties for poorly soluble drug (Löbmann and Svagan 2017). CNFs can generally be converted into aerogel form during drug adsorption and subsequent freeze-drying (Bhandari et al. 2017). Plant-based CNFs have been successfully used as an injectable drug-releasing hydrogel in mice, demonstrating the potential application of CNFs as a matrix for controlled release or targeted local delivery of drug compounds in humans (Laurén et al. 2014).

CA nanofiber mats have been used mainly in diverse pharmaceutical applications due to their advantageous characteristics, like high shear strength and shear modulus, biocompatibility, regenerative properties, high affinity with other substances, biodegradability, and suitable flexural and tensile strength. In particular, CA-based drugloaded nanofibers have received considerable attention in the development of topical and transdermal drug delivery systems (Yu et al. 2013). Besides, cellulose acetate phthalate is a novel material that provides the most efficient solution for $\mathrm{pH}$-controlled drug release. One of the decisive applications of cellulose acetate phthalate is in microencapsulation, which is utilized in an aqueous or organic medium (Wan and Chui 1995). Cellulose acetate phthalate electrospun fibers facilitate resistance to HIV infections. These fibers, even after dissolution, are nontoxic for vaginal epithelial cells and vaginal lactobacilli. These fibers are suitable for loading antiHIV drugs and in preventing HIV infection during sexual intercourse (Huang et al. 2012). Typically, microencapsulation with cellulose acetate phthalate has been done by coacervation phase separation, spray-drying, and extrusion methods (Wan and Chui 1995).

One of the most prevalent hydrophilic biodegradable polymers that has been used in controlledrelease formulations and that has been approved by the United States Food and Drug Administration (FDA), is hydroxy propyl methyl cellulose (Hu et al. 2018). Injectable chitosan/glycerophosphate thermosensitive solutions containing vancomycin-loaded hydroxy propyl methyl cellulose microparticles are produced for the local treatment of osteomyelitis (Mahmoudian and Ganji 2017). The porous and spongy structure of a hydroxyl propyl methyl 
cellulose hydrogel allows for a long-term release profile in vitro, which provides excellent potential for usage in sustained antibiotic delivery (Mahmoudian and Ganji 2017).

\section{Conclusions}

Over the last decades, numerous studies have reported on the modification and utilization of cellulosic materials. This review summarized the preparation of cellulose and its derivatives from different sources, with a focus on specific properties that include structure at molecular and microscopic levels, solubility in certain liquids, and mechanical properties, with further emphasis on their versatility for applications in the biomedical field. Recent advances show that cellulosic materials prove to have inherent characteristics that can be tailored for a broad range of biomedical applications, in tissue engineering, and for the development of drug delivery and wound dressing systems. Several chemical derivatizations and/or modifications that are reported here have been utilized to alter specific cellulose properties for expanding the range of applications, especially biomedical applications. In particular, hydroxyethyl cellulose and CMC are used since they are ideal as versatile materials for tissue engineering. Further, CA, which promotes tissue regeneration in wound dressing preparations, provides patient comfort. BC and cellulose nanocrystals are used for encapsulation. Carboxymethyl cellulose, hydroxy propyl methyl cellulose, ethyl cellulose, and cellulose sulfate are used in drug delivery systems for controlled release. Therefore, although cellulosic materials are traditionally used in everyday household items as paper and textile, they exhibit the necessary qualities for developing novel materials for biomedical applications.

\section{Future perspectives}

Cellulose provides a sustainable resource satisfying the requirements as biomedical material; it has continuously inspired researchers to exploit cellulose-based materials with novel functionalities. Undoubtedly, cellulosic materials hold excellent promise for applications in biological implants and scaffolds for tissue engineering, wound and burn dressing material, medical implants, and drug delivery systems because of their excellent physical and biological properties, biocompatibility, biodegradability, and low cytotoxicity. The surface functionalization and the form of cellulose used for biomedical applications, e.g. hydrogel, solid film, scaffold, membrane, and nanomaterials, provides a useful and powerful tool to tune the interactions of biomaterials with living tissue. Preliminary studies on cellulosic materials have shown that they are favorable biomaterials compared to many other natural polymers in tissue engineering due to their durability and compatibility. The usefulness of cellulosic materials in wound-healing and organ replacement applications has been shown and commercialized, but more interdisciplinary research is still needed to further develop these materials. For instance, a wide variety of mammalian cells needs to be cultured on cellulosic materials to assess their viability and proliferation in vitro. In vivo studies will also be essential to prove its usefulness and functionality for future biomedical applications. Future applications of cellulose and its derivatives are already envisioned in the pharmaceutical industry to act as drug delivery systems, and/or smart artificial skin or wound regeneration therapies. Although cellulosic materials are not inherently toxic, more research is needed to evaluate the potential pharmaceutical side effects and cytotoxicity profile. Cellulose' hydrophilic nature, leading to a poor dispersion in hydrophobic polymer matrices, together with its cytotoxicity, has led to the devotion of much effort on surface modification of cellulosic materials. Various surface and/or bulk modifications of cellulose offer new opportunities for developing unique functional materials. Meanwhile, modification results in alterations of physicochemical properties of materials, especially at the nanoscale. Therefore, the influence of foreign molecule incorporation on the cytotoxicity and/or biocompatibility of nanocellulose should be specifically addressed in future research. Clearly, despite the significant developments concerning biomedical nanocellulosic materials, this area is still in its infancy. We believe that there are still several areas that need to be addressed and plenty of possibilities to be explored on this topic. 
Acknowledgments The authors would like to thank Dr. Peter Olsén for valuable comments on cellulose derivatives.

Authors' contributions Hadi Seddiqi, Erfan Oliaei, Hengameh Honarkar, Jianfeng Jin, Lester C. Geonzon, Rommel G. Bacabac, and Jenneke Klein-Nulend made substantial contributions to the conception or design of the work, drafted the work or revised it critically for important intellectual content, approved the version to be published, and agree to be accountable for all aspects of the work in ensuring that questions related to the accuracy or integrity of any part of the work are appropriately investigated and resolved.

Funding Erfan Oliaei was supported by the Stiftelsen för Strategisk Forskning (Grant No. FID15-0115). The work of Jianfeng Jin was granted by the China Scholarship Council (CSC, No. 201608530156). Lester C. Geonzon was supported by the JSPS KAKENHI (Grant No. 20K13819). Rommel G. Bacabac was funded by the Philippine Council for Industry, Energy and Emerging Technology Research and Development - Department of Science and Technology project no. 04310, and received logistic support from the University of San Carlos Research Office and Department of Physics.

Availability of data and material Not applicable.

Code availability Not applicable.

\section{Compliance with ethical standards}

Conflict of interest All authors have no conflicts of interest.

Open Access This article is licensed under a Creative Commons Attribution 4.0 International License, which permits use, sharing, adaptation, distribution and reproduction in any medium or format, as long as you give appropriate credit to the original author(s) and the source, provide a link to the Creative Commons licence, and indicate if changes were made. The images or other third party material in this article are included in the article's Creative Commons licence, unless indicated otherwise in a credit line to the material. If material is not included in the article's Creative Commons licence and your intended use is not permitted by statutory regulation or exceeds the permitted use, you will need to obtain permission directly from the copyright holder. To view a copy of this licence, visit http://creativecommons.org/licenses/by/4.0/.

\section{References}

Abbott AP, Bell TJ, Handa S, Stoddart B (2005) O-Acetylation of cellulose and monosaccharides using a zinc based ionic liquid. Green Chem 7:705-707. https://doi.org/10.1039/ b511691k

Abe K, Nakatsubo F, Yano H (2009) High-strength nanocomposite based on fibrillated chemi- thermomechanical pulp. Compos Sci Technol 69:24342437. https://doi.org/10.1016/j.compscitech.2009.06.015

Abeer MM, Amin MCIM, Lazim AM, Pandey M, Martin C (2014) Synthesis of a novel acrylated abietic acid-g-bacterial cellulose hydrogel by gamma irradiation. Carbohydr Polym 110:505-512. https://doi.org/10.1016/j.carbpol. 2014.04.052

Abraham E, Weber DE, Sharon S, Lapidot S, Shoseyov O (2017) Multifunctional cellulosic scaffolds from modified cellulose nanocrystals. ACS Appl Mater Inter 9:20102015. https://doi.org/10.1021/acsami.6b13528

Adachi S, Ebi Y, Nishikawa S-i, Hayashi S-i, Yamazaki M, Kasugai T, Yamamura T, Nomura S, Kitamura Y (1992) Necessity of extracellular domain of W (c-kit) receptors for attachment of murine cultured mast cells to fibroblasts. Blood 79:650-656. https://doi.org/10.1182/blood.v79.3. 650.650

Agis H, Beirer B, Watzek G, Gruber R (2010) Effects of carboxymethylcellulose and hydroxypropylmethylcellulose on the differentiation and activity of osteoclasts and osteoblasts. J Biomed Mater Res A 95:504-509. https://doi.org/10.1002/jbm.a.32842

Agoda-Tandjawa G, Durand S, Berot S, Blassel C, Gaillard C, Garnier C, Doublier J-L (2010) Rheological characterization of microfibrillated cellulose suspensions after freezing. Carbohydr Polym 80:677-686. https://doi.org/ 10.1016/j.carbpol.2009.11.045

Agubata CO, Okereke C, Nzekwe IT, Onoja RI, Obitte NC (2016) Development and evaluation of wound healing hydrogels based on a quinolone, hydroxypropyl methylcellulose and biodegradable microfibres. Eur J Pharm Sci 89:1-10. https://doi.org/10.1016/j.ejps.2016.04.017

Ahlfeld T, Köhler T, Czichy C, Lode A, Gelinsky M (2018) A methylcellulose hydrogel as support for 3D plotting of complex shaped calcium phosphate scaffolds. Gels 4:68. https://doi.org/10.3390/gels4030068

Ali ZM, Gibson LJ (2012) The structure and mechanics of nanofibrillar cellulose foams. Soft Matter 9:1580-1588. https://doi.org/10.1039/c2sm27197d

Angles MN, Dufresne A (2000) Plasticized starch/tunicin whiskers nanocomposites. 1. Structural analysis. Macromolecules 33:8344-8353. https://doi.org/10. 1021/ma0008701

Ansari F, Sjöstedt A, Larsson PT, Berglund LA, Wågberg L (2015) Hierarchical wood cellulose fiber/epoxy biocomposites-Materials design of fiber porosity and nanostructure. Compos Part A-Appl Sci 74:60-68. https://doi.org/10.1016/j.compositesa.2015.03.024

Ao C, Niu Y, Zhang X, He X, Zhang W, Lu C (2017) Fabrication and characterization of electrospun cellulose/nanohydroxyapatite nanofibers for bone tissue engineering. Int J Biol Macromol 97:568-573. https://doi.org/10.1016/j. ijbiomac.2016.12.091

Aoshima M, Jo Y (2013) Augmentation for cell spreading and migration by a soluble fraction of cotton-derived carboxymethyl cellulose. Kobunshi Ronbunshu 70:273-281. https://doi.org/10.1295/koron.70.273

Araki J, Kuga S (2001) Effect of trace electrolyte on liquid crystal type of cellulose microcrystals. Langmuir 17:4493-4496. https://doi.org/10.1021/la0102455 
Ardanuy M, Claramunt J, Toledo Filho RD (2015) Cellulosic fiber reinforced cement-based composites: a review of recent research. Constr Build Mater 79:115-128. https://doi.org/10.1016/j.conbuildmat.2015.01.035

Ates B, Koytepe S, Ulu A, Gurses C, Thakur VK (2020) Chemistry, structures, and advanced applications of nanocomposites from biorenewable resources. Chem Rev 120:9304-9362. https://doi.org/10.1021/acs.chemrev. $9 \mathrm{~b} 00553$

Atila D, Keskin D, Tezcaner A (2016) Crosslinked pullulan/cellulose acetate fibrous scaffolds for bone tissue engineering. Mater Sci Eng C-Mater 69:1103-1115. https://doi.org/10.1016/j.msec.2016.08.015

Avolio R, Bonadies I, Capitani D, Errico ME, Gentile G, Avella M (2012) A multitechnique approach to assess the effect of ball milling on cellulose. Carbohydr Polym 87:265-273. https://doi.org/10.1016/j.carbpol.2011.07. 047

Aysu T, Maroto-Valer MM, Sanna A (2016) Ceria promoted deoxygenation and denitrogenation of Thalassiosira weissflogii and its model compounds by catalytic in situ pyrolysis. Bioresour Technol 208:140-148. https://doi. org/10.1016/j.biortech.2016.02.050

Bäckdahl H, Helenius G, Bodin A, Nannmark U, Johansson BR, Risberg B, Gatenholm P (2006) Mechanical properties of bacterial cellulose and interactions with smooth muscle cells. Biomaterials 27:2141-2149. https://doi.org/ 10.1016/j.biomaterials.2005.10.026

Bäckdahl H, Esguerra M, Delbro D, Risberg B, Gatenholm P (2008) Engineering microporosity in bacterial cellulose scaffolds. J Tissue Eng Regen Med 2:320-330. https://doi. org/10.1002/term.97

Balakrishnan P, Gopi S, Geethamma V, Kalarikkal N, Thomas $S$ (2018a) Cellulose nanofiber vs nanocrystals from pineapple leaf fiber: a comparative studies on reinforcing efficiency on starch nanocomposites. Macromol Symp 380:1800102. https://doi.org/10.1002/masy.201800102

Balakrishnan P, Gopi S, Sreekala MS, Thomas S (2018b) UV resistant transparent bionanocomposite films based on potato starch/cellulose for sustainable packaging. StarchStärke 70:1700139. https://doi.org/10.1002/star. 201700139

Barikani M, Oliaei E, Seddiqi H, Honarkar H (2014) Preparation and application of chitin and its derivatives: a review. Iran Polym J 23:307-326. https://doi.org/10.1007/ s13726-014-0225-Z

Basu A, Celma G, Strømme M, Ferraz N (2018a) In vitro and in vivo evaluation of the wound healing properties of nanofibrillated cellulose hydrogels. ACS Appl Bio Mater 1:1853-1863. https://doi.org/10.1021/acsabm.8b00370

Basu P, Saha N, Alexandrova R, Andonova-Lilova B, Georgieva M, Miloshev G, Saha P (2018b) Biocompatibility and biological efficiency of inorganic calcium filled bacterial cellulose based hydrogel scaffolds for bone bioengineering. Int J Mol Sci 19:3980. https://doi.org/10. 3390/ijms 19123980

Battista OA, Smit PA (1962) Microcrystalline cellulose. Ind Eng Chem 54:20-29. https://doi.org/10.1021/ie50633a003

Benítez AJ, Walther A (2017) Cellulose nanofibril nanopapers and bioinspired nanocomposites: a review to understand the mechanical property space. J Mater Chem A 5:1600316024. https://doi.org/10.1039/c7ta02006f

Benítez AJ, Torres-Rendon J, Poutanen M, Walther A (2013) Humidity and multiscale structure govern mechanical properties and deformation modes in films of native cellulose nanofibrils. Biomacromol 14:4497-4506. https://doi.org/10.1021/bm401451m

Bergenstråhle M, Wohlert J, Himmel ME, Brady JW (2010) Simulation studies of the insolubility of cellulose. Carbohydr Res 345:2060-2066. https://doi.org/10.1016/ j.carres.2010.06.017

Berglund JD, Mohseni MM, Nerem RM, Sambanis A (2003) A biological hybrid model for collagen-based tissue engineered vascular constructs. Biomaterials 24:1241-1254. https://doi.org/10.1016/s0142-9612(02)00506-9

Berlioz S, Molina-Boisseau S, Nishiyama Y, Heux L (2009) Gas-phase surface esterification of cellulose microfibrils and whiskers. Biomacromol 10:2144-2151. https://doi. org/10.1021/bm900319k

Berrill N (1947) The structure, development and budding of the ascidian, Eudistoma. J Morphol 81:269-281. https://doi. org/10.1002/jmor.1050810208

Bhandari J, Mishra H, Mishra PK, Wimmer R, Ahmad FJ, Talegaonkar S (2017) Cellulose nanofiber aerogel as a promising biomaterial for customized oral drug delivery. Int J Nanomed 12:2021. https://doi.org/10.2147/ijn. s124318

Bianchi SE, Machado BE, da Silva MG, da Silva MM, Dal Bosco L, Marques MS, Horn AP, Persich L, Geller FC, Argenta D (2018) Coumestrol/hydroxypropyl- $\beta$-cyclodextrin association incorporated in hydroxypropyl methylcellulose hydrogel exhibits wound healing effect: in vitro and in vivo study. Eur J Pharm Sci 119:179-188. https://doi.org/10.1016/j.ejps.2018.04.019

Bidlack J, Buxton D (1992) Content and deposition rates of cellulose, hemicellulose, and lignin during regrowth of forage grasses and legumes. Can J Plant Sci 72:809-818. https://doi.org/10.4141/cjps92-097

Bilbao R, Mastral J, Aldea M, Ceamanos J (1997) Kinetic study for the thermal decomposition of cellulose and pine sawdust in an air atmosphere. J Anal Appl Pyrol 39:5364. https://doi.org/10.1016/s0165-2370(96)00957-6

Birkheur S, de Sousa Faria-Tischer PC, Tischer CA, Pimentel EF, Fronza M, Endringer DC, Butera AP, Ribeiro-Viana RM (2017) Enhancement of fibroblast growing on the mannosylated surface of cellulose membranes. Mater Sci Eng C Mater Biol Appl 77:672-679. https://doi.org/10. 1016/j.msec.2017.04.006

Bledzki AK, Gassan J (1999) Composites reinforced with cellulose based fibres. Prog Polym Sci 24:221-274. https://doi.org/10.1016/s0079-6700(98)00018-5

Bodin A, Ahrenstedt L, Fink H, Brumer H, Risberg B, Gatenholm P (2007) Modification of nanocellulose with a xyloglucan-RGD conjugate enhances adhesion and proliferation of endothelial cells: implications for tissue engineering. Biomacromol 8:3697-3704. https://doi.org/ $10.1021 / \mathrm{bm} 070343 \mathrm{q}$

Brown AJ (1886) XLIII.-On an acetic ferment which forms cellulose. J Chem Soc T 49:432-439. https://doi.org/10. $1039 /$ ct8864900432 
Brown RM Jr, Saxena IM, Kudlicka K (1996) Cellulose biosynthesis in higher plants. Trends Plant Sci 1:149-156. https://doi.org/10.1016/s1360-1385(96)80050-1

Buhus G, Popa M, Desbrieres J (2009) Hydrogels based on carboxymethylcellulose and gelatin for inclusion and release of chloramphenicol. J Bioact Compat Pol 24:525545. https://doi.org/10.1177/0883911509349687

Cai J, Zhang L (2005) Rapid dissolution of cellulose in LiOH/ urea and $\mathrm{NaOH} /$ urea aqueous solutions. Macromol Biosci 5:539-548. https://doi.org/10.1002/mabi.200400222

Campano C, Balea A, Blanco A, Negro C (2016) Enhancement of the fermentation process and properties of bacterial cellulose: a review. Cellulose 23:57-91. https://doi.org/ 10.1007/s10570-015-0802-0

Canas-Gutierrez A, Osorio M, Molina-Ramírez C, ArboledaToro D, Castro-Herazo C (2020) Bacterial cellulose: a biomaterial with high potential in dental and oral applications. Cellulose:1-18. https://doi.org/10.1007/s10570020-03456-4

Capanema NS, Mansur AA, de Jesus AC, Carvalho SM, de Oliveira LC, Mansur HS (2018) Superabsorbent crosslinked carboxymethyl cellulose-PEG hydrogels for potential wound dressing applications. Int J Biol Macromol 106:1218-1234. https://doi.org/10.1016/j.ijbiomac. 2017.08.124

Castro C, Zuluaga R, Putaux J-L, Caro G, Mondragon I, Gañán P (2011) Structural characterization of bacterial cellulose produced by Gluconacetobacter swingsii sp. from Colombian agroindustrial wastes. Carbohydr Polym 84:96-102. https://doi.org/10.1016/j.carbpol.2010.10.072

Catalán J, Ilves M, Järventaus H, Hannukainen KS, Kontturi E, Vanhala E, Alenius H, Savolainen KM, Norppa H (2015) Genotoxic and immunotoxic effects of cellulose nanocrystals in vitro. Environ Mol Mutagen 56:171-182. https://doi.org/10.1002/em.21913

Chahal S, Hussain FSJ, Kumar A, Rasad MSBA, Yusoff MM (2016) Fabrication, characterization and in vitro biocompatibility of electrospun hydroxyethyl cellulose/poly (vinyl) alcohol nanofibrous composite biomaterial for bone tissue engineering. Chem Eng Sci 144:17-29. https://doi.org/10.1016/j.ces.2015.12.030

Chainoglou E, Karagkiozaki V, Choli-Papadopoulou T, Mavromanolis C, Laskarakis A, Logothetidis S (2016) Development of biofunctionalized cellulose acetate nanoscaffolds for heart valve tissue engineering. World $\mathrm{J}$ Nano Sci Eng 6:129-152. https://doi.org/10.4236/wjnse. 2016.64013

Chang PR, Ai F, Chen Y, Dufresne A, Huang J (2009) Effects of starch nanocrystal-graft-polycaprolactone on mechanical properties of waterborne polyurethane-based nanocomposites. J Appl Polym Sci 111:619-627. https://doi.org/10.1002/app.29060

Chen S, Zou Y, Yan Z, Shen W, Shi S, Zhang X, Wang H (2009) Carboxymethylated-bacterial cellulose for copper and lead ion removal. J Hazard Mater 161:1355-1359. https://doi.org/10.1016/j.jhazmat.2008.04.098

Chen D, Lawton D, Thompson M, Liu Q (2012) Biocomposites reinforced with cellulose nanocrystals derived from potato peel waste. Carbohydr Polym 90:709-716. https://doi.org/ 10.1016/j.carbpol.2012.06.002
Chen J, Xu J, Wang K, Cao X, Sun R (2016a) Cellulose acetate fibers prepared from different raw materials with rapid synthesis method. Carbohydr Polym 137:685-692. https://doi.org/10.1016/j.carbpol.2015.11.034

Chen YW, Lee HV, Juan JC, Phang S-M (2016b) Production of new cellulose nanomaterial from red algae marine biomass Gelidium elegans. Carbohydr Polym 151:12101219. https://doi.org/10.1016/j.carbpol.2016.06.083

Cheng Q, Wang S, Harper DP (2009) Effects of process and source on elastic modulus of single cellulose fibrils evaluated by atomic force microscopy. Compos Part A-Appl S 40:583-588. https://doi.org/10.1016/j.compos itesa.2009.02.011

Cheng HN, Dowd MK, Selling GW, Biswas A (2010) Synthesis of cellulose acetate from cotton byproducts. Carbohydr Polym 80:449-452. https://doi.org/10.1016/ j.carbpol.2009.11.048

Chinga-Carrasco G (2011) Cellulose fibres, nanofibrils and microfibrils: the morphological sequence of MFC components from a plant physiology and fibre technology point of view. Nanoscale Res Lett 6:417. https://doi.org/ $10.1186 / 1556-276 x-6-417$

Clermont L, Manery N (1974) Modified cellulose acetate prepared from acetic anhydride reacted with cellulose dissolved in a chloral-dimethylformamide mixture. J Appl Polym Sci 18:2773-2784. https://doi.org/10.1002/ app.1974.070180918

Coelho CC, Michelin M, Cerqueira MA, Gonçalves C, Tonon RV, Pastrana LM, Freitas-Silva O, Vicente AA, Cabral LM, Teixeira JA (2018) Cellulose nanocrystals from grape pomace: production, properties and cytotoxicity assessment. Carbohydr Polym 192:327-336. https://doi. org/10.1016/j.carbpol.2018.03.023

Courtenay JC, Johns MA, Galembeck F, Deneke C, Lanzoni EM, Costa CA, Scott JL, Sharma RI (2017) Surface modified cellulose scaffolds for tissue engineering. Cellulose 24:253-267. https://doi.org/10.1007/s10570-0161111-y

Courtenay JC, Deneke C, Lanzoni EM, Costa CA, Bae Y, Scott JL, Sharma RI (2018) Modulating cell response on cellulose surfaces; tunable attachment and scaffold mechanics. Cellulose 25:925-940. https://doi.org/10. 1007/s10570-017-1612-3

Czaja W, Krystynowicz A, Bielecki S, Brown RM Jr (2006) Microbial cellulose- the natural power to heal wounds. Biomaterials 27:145-151. https://doi.org/10.1016/j.bioma terials.2005.07.035

Dai L, Liu R, Hu L-Q, Wang J-H, Si C-L (2017) Self-assembled PEG-carboxymethylcellulose nanoparticles/ $\alpha$ cyclodextrin hydrogels for injectable and thermosensitive drug delivery. RSC Adv 7:2905-2912. https://doi.org/10. 1039/c6ra25793c

Dairi N, Ferfera-Harrar H, Ramos M, Garrigós MC (2019) Cellulose acetate/agnps-organoclay and/or thymol nanobiocomposite films with combined antimicrobial/antioxidant properties for active food packaging use. Int $\mathbf{J}$ Biol Macromol 121:508-523. https://doi.org/10.1016/j.ijbio mac.2018.10.042

Davidovich-Pinhas M, Barbut S, Marangoni A (2015) The gelation of oil using ethyl cellulose. Carbohydr Polym 
117:869-878. https://doi.org/10.1016/j.carbpol.2014.10. 035

De Dicastillo CL, Bustos F, Guarda A, Galotto MJ (2016) Cross-linked methyl cellulose films with murta fruit extract for antioxidant and antimicrobial active food packaging. Food Hydrocolloid 60:335-344. https://doi. org/10.1016/j.foodhyd.2016.03.020

De Oliveira Ribeiro WC, da Silva Lima AC, de Araújo Morandim-Giannetti A (2018) Optimizing treatment condition of coir fiber with ionic liquid and subsequent enzymatic hydrolysis for future bioethanol production. Cellulose 25:527-536. https://doi.org/10.1007/s10570-017-1554-9

De Rodriguez NLG, Thielemans W, Dufresne A (2006) Sisal cellulose whiskers reinforced polyvinyl acetate nanocomposites. Cellulose 13:261-270. https://doi.org/10. 1007/s10570-005-9039-7

Debzi E, Chanzy H, Sugiyama J, Tekely P, Excoffier G (1991) The $\mathrm{I} \alpha \rightarrow \mathrm{I} \beta$ transformation of highly crystalline cellulose by annealing in various mediums. Macromolecules 24:6816-6822. https://doi.org/10.1021/ma00026a002

Dinand E, Chanzy H, Vignon M (1996) Parenchymal cell cellulose from sugar beet pulp: preparation and properties. Cellulose 3:183-188. https://doi.org/10.1007/bf02228800

Duan H, Shao Z, Zhao M, Zhou Z (2016) Preparation and properties of environmental-friendly coatings based on carboxymethyl cellulose nitrate ester \& modified alkyd. Carbohydr Polym 137:92-99. https://doi.org/10.1016/ j.carbpol.2015.10.067

Dufresne A (2013) Nanocellulose: a new ageless bionanomaterial. Mater Today 16:220-227. https://doi.org/10.1016/ j.mattod.2013.06.004

Dufresne A (2017) Cellulose nanomaterial reinforced polymer nanocomposites. Curr Opin Colloid Interface Sci 29:1-8. https://doi.org/10.1016/j.cocis.2017.01.004

Dumitriu C, Voicu SI, Muhulet A, Nechifor G, Popescu S, Ungureanu C, Carja A, Miculescu F, Trusca R, Pirvu C (2018) Production and characterization of cellulose acetate-titanium dioxide nanotubes membrane fraxiparinized through polydopamine for clinical applications. Carbohydr Polym 181:215-223. https://doi.org/10.1016/ j.carbpol.2017.10.082

Durand-Cavagna G, Delort P, Duprat P, Bailly Y, Plazonnet B, Gordon L (1989) Corneal toxicity studies in rabbits and dogs with hydroxyethyl cellulose and benzalkonium chloride. Toxicol Sci 13:500-508. https://doi.org/10.1016/ 0272-0590(89)90286-8

Ebeling T, Paillet M, Borsali R, Diat O, Dufresne A, Cavaille J, Chanzy H (1999) Shear-induced orientation phenomena in suspensions of cellulose microcrystals, revealed by small angle X-ray scattering. Langmuir 15:6123-6126. https://doi.org/10.1021/la990046+

Edgar KJ, Buchanan CM, Debenham JS, Rundquist PA, Seiler BD, Shelton MC, Tindall D (2001) Advances in cellulose ester performance and application. Prog Poly Sci 26:1605-1688. https://doi.org/10.1016/S0079-6700(01) 00027-2

Eichhorn SJ, Dufresne A, Aranguren M, Marcovich N, Capadona J, Rowan S, Weder C, Thielemans W, Roman M, Renneckar S (2010) Current international research into cellulose nanofibres and nanocomposites. J Mater Sci 45:1-33. https://doi.org/10.1007/s10853-009-3874-0
Elazzouzi-Hafraoui S, Nishiyama Y, Putaux J-L, Heux L, Dubreuil F, Rochas C (2008) The shape and size distribution of crystalline nanoparticles prepared by acid hydrolysis of native cellulose. Biomacromol 9:57-65. https://doi.org/10.1021/bm700769p

Elhawary IA (2015) Fibre to yarn: staple-yarn spinning. In: Textiles and fashion, 1st edn Woodhead Publishing, Cambridge, pp 291-212

Erdmenger T, Haensch C, Hoogenboom R, Schubert US (2007) Homogeneous tritylation of cellulose in 1-butyl-3methylimidazolium chloride. Macromol Biosci 7:440445. https://doi.org/10.1002/mabi.200600253

Falkowitz A, Piech F (1956) Cellulose lacquers-nitrocellulose lacquers for aircraft. Ind Eng Chem 48:1326. https://doi. org/10.1021/ie50560a606

Fan X, Yang L, Wang T, Sun T, Lu S (2019) pH-responsive cellulose-based dual drug-loaded hydrogel for wound dressing. Eur Polym J 109290. https://doi.org/10.1016/j. eurpolymj.2019.109290

Farzamfar S, Naseri-Nosar M, Vaez A, Esmaeilpour F, Ehterami A, Sahrapeyma H, Samadian H, Hamidieh A-A, Ghorbani S, Goodarzi A (2018) Neural tissue regeneration by a gabapentin-loaded cellulose acetate/gelatin wetelectrospun scaffold. Cellulose 25:1229-1238. https://doi. org/10.1007/s10570-017-1632-z

Fernandes AN, Thomas LH, Altaner CM, Callow P, Forsyth VT, Apperley DC, Kennedy CJ, Jarvis MC (2011) Nanostructure of cellulose microfibrils in spruce wood. Proc Natl Acad Sci USA 108:E1195-E1203. https://doi. org/10.1073/pnas.1108942108

Ferrer A, Filpponen I, Rodríguez A, Laine J, Rojas OJ (2012) Valorization of residual empty palm fruit bunch fibers (EPFBF) by microfluidization: production of nanofibrillated cellulose and EPFBF nanopaper. Bioresource Technol 125:249-255. https://doi.org/10.1016/j.biortech. 2012.08.108

Fidale LC, Heinze T, El Seoud OA (2013) Perichromism: a powerful tool for probing the properties of cellulose and its derivatives. Carbohydr Polym 93:129-134. https://doi. org/10.1016/j.carbpol.2012.06.061

French AD (2017) Glucose, not cellobiose, is the repeating unit of cellulose and why that is important. Cellulose 24:46054609. https://doi.org/10.1007/s10570-017-1450-3

Godakanda VU, Li H, Alquezar L, Zhao L, Zhu L-M, de Silva R, de Silva KN, Williams GR (2019) Tunable drug release from blend poly (vinyl pyrrolidone)-ethyl cellulose nanofibers. Int J Pharm 562:172-179. https://doi.org/10. 1016/j.ijpharm.2019.03.035

Gomaa SF, Madkour TM, Moghannem S, El-Sherbiny IM (2017) New polylactic acid/cellulose acetate-based antimicrobial interactive single dose nanofibrous wound dressing mats. Int $\mathrm{J}$ Biol Macromol 105:1148-1160. https://doi.org/10.1016/j.ijbiomac.2017.07.145

Gopi S, Balakrishnan P, Divya C, Valic S, Bajsic EG, Pius A, Thomas S (2017) Facile synthesis of chitin nanocrystals decorated on 3D cellulose aerogels as a new multi-functional material for waste water treatment with enhanced anti-bacterial and anti-oxidant properties. New J Chem 41:12746-12755. https://doi.org/10.1039/c7nj02392h

Gorgieva S, Trček J (2019) Bacterial cellulose: production, modification and perspectives in biomedical applications. 
Nanomaterials 9:1352. https://doi.org/10. 3390/nano9101352

Gouma P, Xue R, Goldbeck C, Perrotta P, Balázsi C (2012) Nano-hydroxyapatite-Cellulose acetate composites for growing of bone cells. Mat Sci Eng C-Mater 32:607-612. https://doi.org/10.1016/j.msec.2011.12.019

Guhados G, Wan W, Hutter JL (2005) Measurement of the elastic modulus of single bacterial cellulose fibers using atomic force microscopy. Langmuir 21:6642-6646. https://doi.org/10.1021/la0504311

Guimard NK, Gomez N, Schmidt CE (2007) Conducting polymers in biomedical engineering. Prog Polym Sci 32:876-921. https://doi.org/10.1016/j.progpolymsci.2007. 05.012

Gumrah Dumanli A (2017) Nanocellulose and its composites for biomedical applications. Curr Med Chem 24:512-528. https://doi.org/10.2174/0929867323666161014124008

Gunduz O, Ahmad Z, Stride E, Edirisinghe M (2013) Continuous generation of ethyl cellulose drug delivery nanocarriers from microbubbles. Pharm Res 30:225-237. https://doi.org/10.1007/s11095-012-0865-7

Guo HX, Heinämäki J, Yliruusi J (2002) Amylopectin as a subcoating material improves the acidic resistance of enteric-coated pellets containing a freely soluble drug. Int J Pharm 235:79-86. https://doi.org/10.1016/s0378-5173 (01)00978-4

Guo J, Uddin KMA, Mihhels K, Fang W, Pi Laaksonen, Zhu J, Rojas OJ (2017) Contribution of residual proteins to the thermomechanical performance of cellulosic nanofibrils isolated from green macroalgae. ACS Sustain Chem Eng 5:6978-6985. https://doi.org/10.1021/acssuschemeng. $7 \mathrm{~b} 01169$

Haafiz MM, Eichhorn S, Hassan A, Jawaid M (2013) Isolation and characterization of microcrystalline cellulose from oil palm biomass residue. Carbohydr Polym 93:628-634. https://doi.org/10.1016/j.carbpol.2013.01.035

Habibi Y, Chanzy H, Vignon MR (2006) TEMPO-mediated surface oxidation of cellulose whiskers. Cellulose 13:679687. https://doi.org/10.1007/s10570-006-9075-y

Habibi Y, Goffin A-L, Schiltz N, Duquesne E, Dubois P, Dufresne A (2008) Bionanocomposites based on poly ( $\varepsilon$ caprolactone)-grafted cellulose nanocrystals by ringopening polymerization. J Mater Chem 18:5002-5010. https://doi.org/10.1039/b809212e

Habibi Y, Lucia LA, Rojas OJ (2010) Cellulose nanocrystals: chemistry, self-assembly, and applications. Chem Rev 110:3479-3500. https://doi.org/10.1021/cr900339w

Håkansson KM, Fall AB, Lundell F, Yu S, Krywka C, Roth SV, Santoro G, Kvick M, Wittberg LP, Wågberg L (2014) Hydrodynamic alignment and assembly of nanofibrils resulting in strong cellulose filaments. Nat Commun 5:4018. https://doi.org/10.1038/ncomms5018

Hakkarainen T, Koivuniemi R, Kosonen M, Escobedo-Lucea C, Sanz-Garcia A, Vuola J, Valtonen J, Tammela P, Mäkitie A, Luukko K (2016) Nanofibrillar cellulose wound dressing in skin graft donor site treatment. J Control Release 244:292-301. https://doi.org/10.1016/j. jconrel.2016.07.053

Hakulinen R (1988) The use of enzymes for wastewater treatment in the pulp and paper industry-a new possibility. Water Sci Technol 20:251-262. https://doi. org/10.2166/wst.1988.0028

Halib N, Ahmad I, Grassi M, Grassi G (2019) The remarkable three-dimensional network structure of bacterial cellulose for tissue engineering applications. Int J Pharm 566:631640. https://doi.org/10.1016/j.ijpharm.2019.06.017

Hallac BB, Ragauskas AJ (2011) Analyzing cellulose degree of polymerization and its relevancy to cellulosic ethanol. Biofuel Bioprod Bior 5:215-225. https://doi.org/10.1002/ bbb. 269

Hasan A, Waibhaw G, Saxena V, Pandey LM (2018) Nanobiocomposite scaffolds of chitosan, carboxymethyl cellulose and silver nanoparticle modified cellulose nanowhiskers for bone tissue engineering applications. Int J Biol Macromol 111:923-934. https://doi.org/10.1016/j. ijbiomac.2018.01.089

Heines SV (1944) John Mercer and mercerization, 1844. J Chem Educ 21:430. https://doi.org/10.1021/ed021p430

Heinze T, Pfeiffer K (1999) Studies on the synthesis and characterization of carboxymethylcellulose. Die Angewandte Makromolekulare Chemie 266:37-45. https://doi. org/10.1002/(sici)1522-9505(19990501)266:1\%3c37:aidapmc37\%3e3.0.co; $2-\mathrm{z}$

Heinze T, Dicke R, Koschella A, Kull AH, Klohr E-A, Koch W (2000) Effective preparation of cellulose derivatives in a new simple cellulose solvent. Macromol Chem Phys 201:627-631. https://doi.org/10.1002/(sici)1521-3935 (20000301)201:6\%3c627:aid-macp627\%3e3.0.co;2-y

Henriksson M, Henriksson G, Berglund LA, Lindström T (2007) An environmentally friendly method for enzymeassisted preparation of microfibrillated cellulose (MFC) nanofibers. Eur Polym J 43:3434-3441. https://doi.org/10. 1016/j.eurpolymj.2007.05.038

Henriksson M, Berglund LA, Isaksson P, Lindstrom T, Nishino T (2008) Cellulose nanopaper structures of high toughness. Biomacromol 9:1579-1585. https://doi.org/10.1021/ bm800038n

Henschen J, Illergård J, Larsson PA, Ek M, Wågberg L (2016) Contact-active antibacterial aerogels from cellulose nanofibrils. Colloid Surface B 146:415-422. https://doi. org/10.1016/j.colsurfb.2016.06.031

Herranz J, Vidal-Valverde C, Rojas-Hidalgo E (1981) Cellulose, hemicellulose and lignin content of raw and cooked Spanish vegetables. J Food Sci 46:1927-1933. https://doi. org/10.1111/j.1365-2621.1981.tb04521.x

Herrick FW, Casebier RL, Hamilton JK, Sandberg KR (1983) Microfibrillated cellulose: morphology and accessibility. J Appl Polym Sci: Appl Polym Symp 37:797-813

Hokmabad VR, Davaran S, Aghazadeh M, Rahbarghazi R, Salehi R, Ramazani A (2019) Fabrication and characterization of novel ethyl cellulose-grafted-poly $(\varepsilon-$ caprolactone)/alginate nanofibrous/macroporous scaffolds incorporated with nano-hydroxyapatite for bone tissue engineering. J Biomater Appl 33:1128-1144. https://doi. org/10.1177/0885328218822641

Hong F, Qiu K (2008) An alternative carbon source from konjac powder for enhancing production of bacterial cellulose in static cultures by a model strain Acetobacter aceti subsp. xylinus ATCC 23770. Carbohydr Polym 72:545-549. https://doi.org/10.1016/j.carbpol.2007.09. 015 
Hoo SP, Loh QL, Yue Z, Fu J, Tan TT, Choong C, Chan PP (2013) Preparation of a soft and interconnected macroporous hydroxypropyl cellulose methacrylate scaffold for adipose tissue engineering. J Mater Chem B 1:3107-3117. https://doi.org/10.1039/c3tb00446e

Hooshmand S, Aitomäki Y, Berglund L, Mathew AP, Oksman K (2017) Enhanced alignment and mechanical properties through the use of hydroxyethyl cellulose in solvent-free native cellulose spun filaments. Comput Sci Technol 150:79-86. https://doi.org/10.1016/j.compscitech.2017. 07.011

Horikawa Y, Sugiyama J (2009) Localization of crystalline allomorphs in cellulose microfibril. Biomacromol 10:2235-2239. https://doi.org/10.1021/bm900413k

Hsieh Y-C, Yano H, Nogi M, Eichhorn S (2008) An estimation of the Young's modulus of bacterial cellulose filaments. Cellulose 15:507-513. https://doi.org/10.1007/s10570008-9206-8

Hu Y, Catchmark JM (2011) In vitro biodegradability and mechanical properties of bioabsorbable bacterial cellulose incorporating cellulases. Acta Biomater 7:2835-2845. https://doi.org/10.1016/j.actbio.2011.03.028

Hu Y, Zhang S, Han D, Ding Z, Zeng S, Xiao X (2018) Construction and evaluation of the hydroxypropyl methyl cellulose-sodium alginate composite hydrogel system for sustained drug release. J Polym Res 25:148. https://doi. org/10.1007/s10965-018-1546-y

Hua K, Rocha I, Zhang P, Gustafsson S, Ning Y, Strømme M, Mihranyan A, Ferraz N (2016) Transition from bioinert to bioactive material by tailoring the biological cell response to carboxylated nanocellulose. Biomacromol 17:12241233. https://doi.org/10.1021/acs.biomac.6b00053

Huang H-C, Chen L-C, Lin S-B, Chen H-H (2011) Nanobiomaterials application: in situ modification of bacterial cellulose structure by adding HPMC during fermentation. Carbohydr Polym 83:979-987. https://doi.org/10.1016/ j.carbpol.2010.09.011

Huang C, Soenen SJ, van Gulck E, Vanham G, Rejman J, Van Calenbergh S, Vervaet C, Coenye T, Verstraelen $\mathrm{H}$, Temmerman M, Demeester J, De Smedt SC (2012) Electrospun cellulose acetate phthalate fibers for semen induced anti-HIV vaginal drug delivery. Biomaterials 33:962-969. https://doi.org/10.1016/j.biomaterials.2011. 10.004

Içten E, Purohit HS, Wallace C, Giridhar A, Taylor LS, Nagy ZK, Reklaitis GV (2017) Dropwise additive manufacturing of pharmaceutical products for amorphous and self emulsifying drug delivery systems. Int J Pharm 524:424432. https://doi.org/10.1016/j.ijpharm.2017.04.003

Ioelovich M (2008) Cellulose as a nanostructured polymer: a short review. BioResources 3:1403-1418

Ioniță M, Crică LE, Voicu SI, Dinescu S, Miculescu F, Costache M, Iovu H (2018) Synergistic effect of carbon nanotubes and graphene for high performance cellulose acetate membranes in biomedical applications. Carbohydr Polym 183:50-61. https://doi.org/10.1016/j.carbpol.2017. 10.095

Iqbal HM, Kyazze G, Locke IC, Tron T, Keshavarz T (2015) Poly (3-hydroxybutyrate)-ethyl cellulose based bio-composites with novel characteristics for infection free wound healing application. Int $\mathrm{J}$ Biol Macromol 81:552-559. https://doi.org/10.1016/j.ijbiomac.2015.08.040

Ishikawa A, Okano T, Sugiyama J (1997) Fine structure and tensile properties of ramie fibres in the crystalline form of cellulose I, II, IIII and IVI. Polymer 38:463-468. https://doi.org/10.1016/s0032-3861(96)00516-2

Isogai A, Saito T, Fukuzumi H (2011) TEMPO-oxidized cellulose nanofibers. Nanoscale 3:71-85. https://doi.org/10. 1039/c0nr00583e

Iwamoto S, Kai W, Isogai A, Iwata T (2009) Elastic modulus of single cellulose microfibrils from tunicate measured by atomic force microscopy. Biomacromol 10:2571-2576. https://doi.org/10.1021/bm900520n

Iwamoto S, Isogai A, Iwata T (2011) Structure and mechanical properties of wet-spun fibers made from natural cellulose nanofibers. Biomacromol 12:831-836. https://doi.org/10. 1021/bm101510r

Jahan MS, Mun SP (2009) Studies on the macromolecular components of nonwood available in Bangladesh. Ind Crop Prod 30:344-350. https://doi.org/10.1016/j.indcrop. 2009.06.006

Jalal Uddin A, Araki J, Gotoh Y (2011) Extremely oriented tunicin whiskers in poly (vinyl alcohol) nanocomposites. Polym Int 60:1230-1239. https://doi.org/10.1002/pi.3067

Jeddi MK, Mahkam M (2019) Magnetic nano carboxymethyl cellulose-alginate/chitosan hydrogel beads as biodegradable devices for controlled drug delivery. I Int J Biol Macromol 135:829-838. https://doi.org/10.1016/j.ijbio mac.2019.05.210

Jiang Z, Fang Y, Ma Y, Liu M, Liu R, Guo H, Lu A, Zhang L (2017) Dissolution and metastable solution of cellulose in $\mathrm{NaOH} /$ Thiourea at $8 \mathrm{C}$ for construction of nanofibers. J Phys Chem B 121:1793-1801. https://doi.org/10.1021/ acs.jpcb.6b10829.s001

Jonas R, Farah LF (1998) Production and application of microbial cellulose. Polym Degrad Stabil 59:101-106. https://doi.org/10.1016/s0141-3910(97)00197-3

Jozala A, Pértile R, dos Santos C, de Carvalho Santos-Ebinuma V, Seckler M, Gama F, Pessoa AJ (2015) Bacterial cellulose production by Gluconacetobacter xylinus by employing alternative culture media. Appl Microbiol Biot 99:1181-1190. https://doi.org/10.1007/s00253-014-62323

Juban A, Nouguier-Lehon C, Briancon S, Hoc T, Puel F (2015) Predictive model for tensile strength of pharmaceutical tablets based on local hardness measurements. Int J Pharm 490:438-445. https://doi.org/10.1016/j.ijpharm.2015.05. 078

Kamel S, Ali N, Jahangir K, Shah S, El-Gendy A (2008) Pharmaceutical significance of cellulose: a review. Express Polym Lett 2:758-778. https://doi.org/10. 3144/expresspolymlett.2008.90

Karmazsin E (1987) Thermal analysis in the cellulose, paper and textile industry. Thermochim Acta 110:471-475. https://doi.org/10.1016/0040-6031(87)88260-6

Khoshnevisan K, Maleki H, Samadian H, Shahsavari S, Sarrafzadeh MH, Larijani B, Dorkoosh FA, Haghpanah V, Khorramizadeh MR (2018) Cellulose acetate electrospun nanofibers for drug delivery systems: applications and recent advances. Carbohydr Polym 198:131-141. https://doi.org/10.1016/j.carbpol.2018.06.072 
Kimura S, Ohshima C, Hirose E, Nishikawa J, Itoh T (2001) Cellulose in the house of the appendicularianOikopleura rufescens. Protoplasma 216:71-74. https://doi.org/10. 1007/bf02680133

Klemm D, Heublein B, Fink HP, Bohn A (2005) Cellulose: fascinating biopolymer and sustainable raw material. Angew Chem Int Edit 44:3358-3393. https://doi.org/10. 1002/anie. 200460587

Klemm D, Kramer F, Moritz S, Lindström T, Ankerfors M, Gray D, Dorris A (2011) Nanocelluloses: a new family of nature-based materials. Angew Chem Int Edit 50:54385466. https://doi.org/10.1002/anie.201001273

Klemm D, Cranston ED, Fischer D, Gama M, Kedzior SA, Kralisch D, Kramer F, Kondo T, Lindström T, Nietzsche $S$ (2018) Nanocellulose as a natural source for groundbreaking applications in materials science: today's state. Mater Today 21:720-748. https://doi.org/10.1016/j.mat tod.2018.02.001

Koch W (1937) Properties and uses of ethylcellulose. Ind Eng Chem Res 29:687-690. https://doi.org/10.1021/ ie 50330a020

Koizumi S, Yue Z, Tomita Y, Kondo T, Iwase H, Yamaguchi D, Hashimoto T (2008) Bacterium organizes hierarchical amorphous structure in microbial cellulose. Eur Phys J E 26:137-142. https://doi.org/10.1140/epje/i2007-10259-3

Kolin B, Janezic TS (1996) The effect of temperature, density and chemical composition upon the limit of hygroscopicity of wood. Holzforschung 50:263-268. https://doi.org/ 10.1515/hfsg.1996.50.3.263

Kozlowska J, Stachowiak N, Sionkowska A (2018) Collagen/ gelatin/hydroxyethyl cellulose composites containing microspheres based on collagen and gelatin: design and evaluation. Polymers 10:456. https://doi.org/10.3390/ polym 10040456

Kshirsagar S, Bhalekar M, Shewale N, Godbole V, Jagdale P, Mohapatra S (2011) Development of enzyme-controlled colonic drug delivery using amylose and hydroxypropyl methylcellulose: optimization by factorial design. Drug Deliv 18:385-393. https://doi.org/10.3109/10717544. 2011.567308

Kulterer MR, Reischl M, Reichel VE, Hribernik S, Wu M, Köstler S, Kargl R, Ribitsch V (2011) Nanoprecipitation of cellulose acetate using solvent/nonsolvent mixtures as dispersive media. Colloids Surf A Physicochem Eng Asp 375:23-29. https://doi.org/10.1016/j.colsurfa.2010.11.029

Kumagai A, Endo T (2018) Comparison of the surface constitutions of hemicelluloses on lignocellulosic nanofibers prepared from softwood and hardwood. Cellulose 25:3885-3897. https://doi.org/10.1007/s10570-018-18619

Kumar R, Mago G, Balan V, Wyman CE (2009) Physical and chemical characterizations of corn stover and poplar solids resulting from leading pretreatment technologies. Bioresource Technol 100:3948-3962. https://doi.org/10. 1016/j.biortech.2009.01.075

Kumbhar JV, Jadhav SH, Bodas DS, Barhanpurkar-Naik A, Wani MR, Paknikar KM, Rajwade JM (2017) In vitro and in vivo studies of a novel bacterial cellulose-based acellular bilayer nanocomposite scaffold for the repair of osteochondral defects. Int J Nanomed 12:6437. https://doi. org/10.2147/ijn.s137361
Kurihara T, Isogai A (2015) Mechanism of TEMPO-oxidized cellulose nanofibril film reinforcement with poly (acrylamide). Cellulose 22:2607-2617. https://doi.org/10.1007/ s10570-015-0680-5

Kwak MH, Kim JE, Go J, Koh EK, Song SH, Son HJ, Kim HS, Yun YH, Jung YJ, Hwang DY (2015) Bacterial cellulose membrane produced by Acetobacter sp. A10 for burn wound dressing applications. Carbohydr Polym 122:387398. https://doi.org/10.1016/j.carbpol.2014.10.049

Laurén P, Lou Y-R, Raki M, Urtti A, Bergström K, Yliperttula M (2014) Technetium-99 m-labeled nanofibrillar cellulose hydrogel for in vivo drug release. Eur J Pharm Sci 65:7988. https://doi.org/10.1016/j.ejps.2014.09.013

Le Goff KJ, Gaillard C, Helbert W, Garnier C, Aubry T (2015) Rheological study of reinforcement of agarose hydrogels by cellulose nanowhiskers. Carbohydr Polym 116:117123. https://doi.org/10.1016/j.carbpol.2014.04.085

L'Heureux N, Germain L, Labbé R, Auger FA (1993) In vitro construction of a human blood vessel from cultured vascular cells: a morphologic study. J Vasc Surg 17:499-509. https://doi.org/10.1016/0741-5214(93)90150-k

Li Q, Zhou J, Zhang L (2009) Structure and properties of the nanocomposite films of chitosan reinforced with cellulose whiskers. J Polym Sci B Polym Phys 47:1069-1077. https://doi.org/10.1002/polb.21711

Li D, Ao K, Wang Q, Lv P, Wei Q (2016a) Preparation of Pd/ bacterial cellulose hybrid nanofibers for dopamine detection. Molecules 21:618. https://doi.org/10. 3390/molecules21050618

Li X, Zhang Y, Tang J, Lan A, Yang Y, Gibril M, Yu M (2016b) Efficient preparation of high concentration cellulose solution with complex DMSO/ILs solvent. J Polym Res 23:32. https://doi.org/10.1007/s10965-016-0922-8

Li H, Zhang Z, Godakanda VU, Chiu Y-J, Angkawinitwong U, Patel K, Stapleton PG, de Silva RM, de Silva KN, Zhu L-M (2019a) The effect of collection substrate on electrospun ciprofloxacin-loaded poly (vinylpyrrolidone) and ethyl cellulose nanofibers as potential wound dressing materials. Mater Sci Eng, C 104:109917. https://doi.org/ 10.1016/j.msec.2019.109917

Li J, Zhang J, Sun H, Hong D, Li L, Yang Y, Yong X, Zhang C, Cui J (2019b) An optical fiber relative humidity sensor based on hollow-core fiber and hydroxypropyl methylcellulose hydrogel film. Optik 195:163172. https://doi.org/ 10.1016/j.ijleo.2019.163172

Liakos IL, Iordache F, Carzino R, Scarpellini A, Oneto M, Bianchini P, Grumezescu AM, Holban AM (2018) Cellulose acetate-essential oil nanocapsules with antimicrobial activity for biomedical applications. Colloids Surf B Biointerfaces 172:471-479. https://doi.org/ 10.1016/j.colsurfb.2018.08.069

Liitiä T, Maunu SL, Hortling B, Tamminen T, Pekkala O, Varhimo A (2003) Cellulose crystallinity and ordering of hemicelluloses in pine and birch pulps as revealed by solid-state NMR spectroscopic methods. Cellulose 10:307-316. https://doi.org/10.1023/A:1027302526861

Lin W-C, Lien C-C, Yeh H-J, Yu C-M, Hsu S-h (2013) Bacterial cellulose and bacterial cellulose-chitosan membranes for wound dressing applications. Carbohydr Polym 94:603-611. https://doi.org/10.1016/j.carbpol. 2013.01.076 
Lindman B, Medronho B, Alves L, Costa C, Edlund H, Norgren $M$ (2017) The relevance of structural features of cellulose and its interactions to dissolution, regeneration, gelation and plasticization phenomena. Phys Chem Chem Phys 19:23704-23718. https://doi.org/10.1039/ c7cp02409f

Lindström T (2017) Aspects on nanofibrillated cellulose (NFC) processing, rheology and NFC-film properties. Curr Opin Colloid Interface Sci 29:68-75. https://doi.org/10.1016/ j.cocis.2017.02.005

Löbmann K, Svagan AJ (2017) Cellulose nanofibers as excipient for the delivery of poorly soluble drugs. Int $\mathrm{J}$ Pharm 533:285-297. https://doi.org/10.1016/j.ijpharm. 2017.09.064

López JP, Méndez JA, N-eE Mansouri, Mutjé P, Vilaseca F (2011) Mean intrinsic tensile properties of stone groundwood fibers from softwood. BioResources 6:5037-5049. https://doi.org/10.1016/j.carbpol.2010.04.073

López JP, Boufi S, El Mansouri NE, Mutjé P, Vilaseca F (2012) PP composites based on mechanical pulp, deinked newspaper and jute strands: a comparative study. Compos B Eng 43:3453-3461. https://doi.org/10.1016/j.compos itesb.2012.01.040

López JP, Gironès J, Mendez JA, Pèlach MA, Vilaseca F, Mutjé P (2013) Impact and flexural properties of stoneground wood pulp-reinforced polypropylene composites. Polym Compos 34:842-848. https://doi.org/10.1002/pc. 22486

Lukanina KI, Grigoriev TE, Krasheninnikov SV, Mamagulashvilli VG, Kamyshinsky RA, Chvalun SN (2018) Multi-hierarchical tissue-engineering ECM-like scaffolds based on cellulose acetate with collagen and chitosan fillers. Carbohydr Polym 191:119-126. https://doi.org/10. 1016/j.carbpol.2018.02.061

Lu P, Hsieh Y-L (2010) Preparation and properties of cellulose nanocrystals: rods, spheres, and network. Carbohydr Polym 82:329-336. https://doi.org/10.1016/j.carbpol. 2010.04.073

Luo H, Cha R, Li J, Hao W, Zhang Y, Zhou F (2019) Advances in tissue engineering of nanocellulose-based scaffolds: a review. Carbohydr Polym 224:115144. https://doi.org/10. 1016/j.carbpol.2019.115144

Madsen B, Gamstedt EK (2013) Wood versus plant fibers: similarities and differences in composite applications. Adv Mater Sci Eng 2013:1-14. https://doi.org/10.1155/ 2013/564346

Mahmoudian M, Ganji F (2017) Vancomycin-loaded HPMC microparticles embedded within injectable thermosensitive chitosan hydrogels. Prog Biomater 6:49-56. https://doi.org/10.1007/s40204-017-0066-x

Mao D, Li Q, Bai N, Dong H, Li D (2018a) Porous stable poly (lactic acid)/ethyl cellulose/hydroxyapatite composite scaffolds prepared by a combined method for bone regeneration. Carbohydr Polym 180:104-111. https://doi. org/10.1016/j.carbpol.2017.10.031

Mao D, Li Q, Li D, Chen Y, Chen X, Xu X (2018b) Fabrication of 3D porous poly (lactic acid)-based composite scaffolds with tunable biodegradation for bone tissue engineering. Mater Des 142:1-10. https://doi.org/10.1016/j.matdes. 2018.01.016
Marques-Marinho FD, Vianna-Soares CD (2013) Cellulose and its derivatives use in the pharmaceutical compounding practice. In: van de Ven T, Godbout L (ed) CelluloseMedical, Pharmaceutical and Electronic Applications, 1st edn. IntechOpen, London, pp141-162. http://dx.doi.org/ $10.5772 / 56637$

Martínez-Sanz M, Lopez-Rubio A, Lagaron JM (2011) Optimization of the nanofabrication by acid hydrolysis of bacterial cellulose nanowhiskers. Carbohydr Polym 85:228-236. https://doi.org/10.1016/j.carbpol.2011.02. 021

Maynard JP (1848) Discovery and application of the new liquid adhesive plaster. Boston Med Surg J 38:178-183. https://doi.org/10.1056/nejm184803290380903

Mertaniemi H, Escobedo-Lucea C, Sanz-Garcia A, Gandía C, Mäkitie A, Partanen J, Ikkala O, Yliperttula M (2016) Human stem cell decorated nanocellulose threads for biomedical applications. Biomaterials 82:208-220. https://doi.org/10.1016/j.biomaterials.2015.12.020

Mondal MIH, Yeasmin MS, Rahman MS (2015) Preparation of food grade carboxymethyl cellulose from corn husk agrowaste. Int J Biol Macromol 79:144-150. https://doi. org/10.1016/j.ijbiomac.2015.04.061

Moon RJ, Martini A, Nairn J, Simonsen J, Youngblood J (2011) Cellulose nanomaterials review: structure, properties and nanocomposites. Chem Soc Rev 40:3941-3994. https://doi.org/10.1039/c0cs00108b

Moraïs S, Heyman A, Barak Y, Caspi J, Wilson DB, Lamed R, Shoseyov O, Bayer EA (2010) Enhanced cellulose degradation by nano-complexed enzymes: synergism between a scaffold-linked exoglucanase and a free endoglucanase. J Biotechnol 147:205-211. https://doi.org/ 10.1016/j.jbiotec.2010.04.012

Morgado DL, Rodrigues BV, Almeida EV, Seoud OAE, Frollini E (2013) Bio-based films from linter cellulose and its acetates: formation and properties. Materials 6:24102435. https://doi.org/10.3390/ma6062410

Mott L, Groom L, Shaler S (2002) Mechanical properties of individual southern pine fibers. Part II. Comparison of earlywood and latewood fibers with respect to tree height and juvenility. Wood Fiber Sci 34:221-237

Mousavi SM, Afra E, Tajvidi M, Bousfield D, DehghaniFirouzabadi M (2017) Cellulose nanofiber/carboxymethyl cellulose blends as an efficient coating to improve the structure and barrier properties of paperboard. Cellulose 24:3001-3014. https://doi.org/10.1007/s10570-017-12995

Müller A, Zink M, Hessler N, Wesarg F, Müller FA, Kralisch D, Fischer D (2014) Bacterial nanocellulose with a shapememory effect as potential drug delivery system. RSC Adv 4:57173-57184. https://doi.org/10.1039/c4ra09898f

Mwesigwa E, Basit AW (2016) An investigation into moisture barrier film coating efficacy and its relevance to drug stability in solid dosage forms. Int J Pharm 497:70-77. https://doi.org/10.1016/j.ijpharm.2015.10.068

Nam S, Hillyer MB, Condon BD (2020) Method for identifying the triple transition (glass transition-dehydration-crystallization) of amorphous cellulose in cotton. Carbohydr Polym 228:115374. https://doi.org/10.1016/j.carbpol. 2019.115374 
Nasatto P, Pignon F, Silveira J, Duarte M, Noseda M, Rinaudo M (2015) Methylcellulose, a cellulose derivative with original physical properties and extended applications. Polymers 7:777-803. https://doi.org/10.3390/ polym 7050777

Nel A, Xia T, Mädler L, Li N (2006) Toxic potential of materials at the nanolevel. Science 311:622-627. https://doi.org/10.1126/science.1114397

Neves A, Angelin EM, Roldão É, Melo MJ (2019) New insights into the degradation mechanism of cellulose nitrate in cinematographic films by Raman microscopy. J Raman Spectrosc 50:202-212. https://doi.org/10.1002/ jrs.5464

Niemczyk-Soczynska B, Gradys A, Kolbuk D, KrztonMaziopa A, Sajkiewicz P (2019) Crosslinking kinetics of methylcellulose aqueous solution and its potential as a scaffold for tissue engineering. Polymers 11:1772. https://doi.org/10.3390/polym11111772

Ninan N, Muthiah M, Park I-K, Elain A, Thomas S, Grohens Y (2013) Pectin/carboxymethyl cellulose/microfibrillated cellulose composite scaffolds for tissue engineering. Carbohydr Polym 98:877-885. https://doi.org/10.1016/ j.carbpol.2013.06.067

Nishiyama Y, Langan P, Chanzy H (2002) Crystal structure and hydrogen-bonding system in cellulose I $\beta$ from synchrotron X-ray and neutron fiber diffraction. J Am Chem Soc 124:9074-9082. https://doi.org/10.1021/ja037055w. s001

Nishiyama Y, Kim U-J, Kim D-Y, Katsumata KS, May RP, Langan P (2003) Periodic disorder along ramie cellulose microfibrils. Biomacromol 4:1013-1017. https://doi.org/ 10.1021/bm025772x

Nsor-Atindana J, Chen M, Goff HD, Zhong F, Sharif HR, Li Y (2017) Functionality and nutritional aspects of microcrystalline cellulose in food. Carbohydr Polym 172:159174. https://doi.org/10.1016/j.carbpol.2017.04.021

Nuutila K, Laukkanen A, Lindford A, Juteau S, Nuopponen M, Vuola J, Kankuri E (2018) Inhibition of skin wound contraction by nanofibrillar cellulose hydrogel. Plast Reconstr Surg 141:357e-366e. https://doi.org/10.1097/ prs.0000000000004168

Ogushi Y, Sakai S, Kawakami K (2007) Synthesis of enzymatically-gellable carboxymethylcellulose for biomedical applications. J Biosci Bioeng 104:30-33. https://doi.org/ 10.1263/jbb.104.30

Oliaei E, Lindén PA, Wu Q, Berthold F, Berglund L, Lindström T (2020) Microfibrillated lignocellulose (MFLC) and nanopaper films from unbleached kraft softwood pulp. Cellulose 27:2325-2341. https://doi.org/10.1007/s10570019-02934-8

Pal N, Dubey P, Gopinath P, Pal K (2017) Combined effect of cellulose nanocrystal and reduced graphene oxide into poly-lactic acid matrix nanocomposite as a scaffold and its anti-bacterial activity. Int J Biol Macromol 95:94-105. https://doi.org/10.1016/j.ijbiomac.2016.11.041

Palaninathan V, Raveendran S, Rochani AK, Chauhan N, Sakamoto Y, Ukai T, Maekawa T, Kumar DS (2018) Bioactive bacterial cellulose sulfate electrospun nanofibers for tissue engineering applications. J Tissue Eng Regen Med 12:1634-1645. https://doi.org/10.1002/term. 2689
Palmer D, Levina M, Nokhodchi A, Douroumis D, Farrell T, Rajabi-Siahboomi A (2011) The influence of sodium carboxymethylcellulose on drug release from polyethylene oxide extended release matrices. AAPS PharmSciTech 12:862. https://doi.org/10.1208/s12249011-9648-4

Pan R, Cheung O, Wang Z, Tammela P, Huo J, Lindh J, Edström K, Strømme M, Nyholm L (2016) Mesoporous Cladophora cellulose separators for lithium-ion batteries. J Power Sources 321:185-192. https://doi.org/10.1016/j. jpowsour.2016.04.115

Pandey M, Mohamad N, Low W-L, Martin C, Amin MCIM (2017) Microwaved bacterial cellulose-based hydrogel microparticles for the healing of partial thickness burn wounds. Drug Delivery Transl Res 7:89-99. https://doi. org/10.1007/s13346-016-0341-8

Park M, Lee D, Shin S, Hyun J (2015) Effect of negatively charged cellulose nanofibers on the dispersion of hydroxyapatite nanoparticles for scaffolds in bone tissue engineering. Colloids Surf B 130:222-228. https://doi.org/ 10.1016/j.colsurfb.2015.04.014

Parveen Kumar DMB, Delwiche Michael J, Stroeve Pieter (2009) Methods for pretreatment of lignocellulosic biomass for efficient hydrolysis and biofuel production. Ind Eng Chem Res 48:3713-3729. https://doi.org/10.1021/ ie $801542 \mathrm{~g}$

Pasqui D, Torricelli P, De Cagna M, Fini M, Barbucci R (2014) Carboxymethyl cellulose-hydroxyapatite hybrid hydrogel as a composite material for bone tissue engineering applications. J Biomed Mater Res, Part A 102:1568-1579. https://doi.org/10.1002/jbm.a.34810

Peciulyte A, Karlström K, Larsson PT, Olsson L (2015) Impact of the supramolecular structure of cellulose on the efficiency of enzymatic hydrolysis. Biotechnol Biofuels 8:56. https://doi.org/10.1186/s13068-015-0236-9

Pei A, Zhou Q, Berglund LA (2010) Functionalized cellulose nanocrystals as biobased nucleation agents in poly (1lactide)(PLLA)-Crystallization and mechanical property effects. Comput Sci Technol 70:815-821. https://doi.org/ 10.1016/j.compscitech.2010.01.018

Petreus T, Stoica BA, Petreus O, Goriuc A, Cotrutz C-E, Antoniac I-V, Barbu-Tudoran L (2014) Preparation and cytocompatibility evaluation for hydrosoluble phosphorous acid-derivatized cellulose as tissue engineering scaffold material. J Mater Sci Mater Med 25:1115-1127. https://doi.org/10.1007/s10856-014-5146-Z

Potthast A, Rosenau T, Buchner R, Röder T, Ebner G, Bruglachner H, Sixta H, Kosma P (2002) The cellulose solvent system $\mathrm{N}$, N-dimethylacetamide/lithium chloride revisited: the effect of water on physicochemical properties and chemical stability. Cellulose 9:41-53. https://doi. org/10.1023/A:1015811712657

Qi P, Ohba S, Hara Y, Fuke M, Ogawa T, Ohta S, Ito T (2018) Fabrication of calcium phosphate-loaded carboxymethyl cellulose non-woven sheets for bone regeneration. Carbohydr Polym 189:322-330. https://doi.org/10.1016/ j.carbpol.2018.02.050

Qiu Y, Qiu L, Cui J, Wei Q (2016) Bacterial cellulose and bacterial cellulose-vaccarin membranes for wound healing. Mater Sci Eng C Mater Biol Appl 59:303-309. https://doi.org/10.1016/j.msec.2015.10.016 
Quadir MA, Chanda E, Haider SS, Reza MS, Datta BK (2005) Evaluation of ethylcellulose as matrices for controlled release drug delivery. Pak J Pharm Sci 18:29-34

Rabemanolontsoa H, Saka S (2013) Comparative study on chemical composition of various biomass species. RSC Adv 3:3946-3956. https://doi.org/10.1039/c3ra22958k

Ramezani MG, Golchinfar B (2019) Mechanical properties of cellulose nanocrystal (CNC) bundles: coarse-grained molecular dynamic simulation. J Compos Sci 3:57. https://doi.org/10.3390/jcs3020057

Ramírez JAÁ, Fortunati E, Kenny JM, Torre L, Foresti ML (2017) Simple citric acid-catalyzed surface esterification of cellulose nanocrystals. Carbohydr Polym 157:13581364. https://doi.org/10.1016/j.carbpol.2016.11.008

Ramli NA, Wong TW (2011) Sodium carboxymethylcellulose scaffolds and their physicochemical effects on partial thickness wound healing. Int $\mathrm{J}$ Pharm 403:73-82. https://doi.org/10.1016/j.ijpharm.2010.10.023

Ramsden M, Blake F (1997) A kinetic study of the acetylation of cellulose, hemicellulose and lignin components in wood. Wood Sci Technol 31:45-50. https://doi.org/10. $1007 / \mathrm{s} 002260050013$

Ranby B (1949) Aqueous colloidal solutions of cellulose micelles. Acta Chem Scand 3:649-650. https://doi.org/10. 3891/acta.chem.scand.03-0649

Rashad A, Mohamed-Ahmed S, Ojansivu M, Berstad K, Yassin MA, Kivijärvi T, Heggset EB, Syverud K, Mustafa K (2018) Coating 3D printed polycaprolactone scaffolds with nanocellulose promotes growth and differentiation of mesenchymal stem cells. Biomacromol 19:4307-4319. https://doi.org/10.1021/acs.biomac.8b01194.s001

Rekhi GS, Jambhekar SS (1995) Ethylcellulose-a polymer review. Drug Dev Ind Pharm 21:61-77. https://doi.org/10. 3109/03639049509048096

Revol J-F (1982) On the cross-sectional shape of cellulose crystallites in Valonia ventricosa. Carbohydr Polym 2:123-134. https://doi.org/10.1016/0144-8617(82)900583

Roberts R, Rowe R (1985) The effect of punch velocity on the compaction of a variety of materials. J Pharm Pharmacol 37:377-384. https://doi.org/10.1111/j.2042-7158.1985. tb03019.x

Robertson I, Rolfe J, Switsur V, Carter A, Hall M, Barker A, Waterhouse J (1997) Signal strength and climate relationships in $13 \mathrm{C} / 12 \mathrm{C}$ ratios of tree ring cellulose from oak in southwest Finland. Geophys Res Lett 24:1487-1490. https://doi.org/10.1029/97gl01293

Rodrigues Filho G, Ribeiro SD, Meireles CdS, da Silva LG, Ruggiero R, Ferreira Junior MF, Cerqueira DA, de Assunção RMN, Zeni M, Polleto P (2011) Release of doxycycline through cellulose acetate symmetric and asymmetric membranes produced from recycled agroindustrial residue: sugarcane bagasse. Ind Crops Prod 33:566-571. https://doi.org/10.1016/j.indcrop.2010.10. 037

Roman M, Winter WT (2004) Effect of sulfate groups from sulfuric acid hydrolysis on the thermal degradation behavior of bacterial cellulose. Biomacromol 5:16711677. https://doi.org/10.1021/bm034519+

Rudisill SG, DiVito MD, Hubel A, Stein A (2015) In vitro collagen fibril alignment via incorporation of nanocrystalline cellulose. Acta Biomater 12:122-128. https://doi.org/10.1016/j.actbio.2014.10.024

Rusli R, Eichhorn SJ (2008) Determination of the stiffness of cellulose nanowhiskers and the fiber-matrix interface in a nanocomposite using Raman spectroscopy. Appl Phys Lett 93:033111. https://doi.org/10.1063/1.2963491

Rusli R, Shanmuganathan K, Rowan SJ, Weder C, Eichhorn SJ (2011) Stress transfer in cellulose nanowhisker composites-influence of whisker aspect ratio and surface charge. Biomacromol 12:1363-1369. https://doi.org/10.1021/ bm200141x

Sacui IA, Nieuwendaal RC, Burnett DJ, Stranick SJ, Jorfi M, Weder C, Foster EJ, Olsson RT, Gilman JW (2014) Comparison of the properties of cellulose nanocrystals and cellulose nanofibrils isolated from bacteria, tunicate, and wood processed using acid, enzymatic, mechanical, and oxidative methods. ACS Appl Mater Inter 6:61276138. https://doi.org/10.1021/am500359f

Sahoo PK, Jena DK (2018) Synthesis and study of mechanical and fire retardant properties of (carboxymethyl celluloseg-polyacrylonitrile)/montmorillonite biodegradable nanocomposite. J Polym Res 25:260. https://doi.org/10. 1007/s10965-018-1659-3

Sajjad W, Khan T, Ul-Islam M, Khan R, Hussain Z, Khalid A, Wahid F (2019) Development of modified montmorillonite-bacterial cellulose nanocomposites as a novel substitute for burn skin and tissue regeneration. Carbohydr Polym 206:548-556. https://doi.org/10.1016/j.carbpol. 2018.11.023

Sakurada I, Nukushina Y, Ito T (1962) Experimental determination of the elastic modulus of crystalline regions in oriented polymers. J Polym Sci 57:651-660. https://doi. org/10.1002/pol.1962.1205716551

Salamat-Miller N, Chittchang M, Johnston TP (2005) The use of mucoadhesive polymers in buccal drug delivery. Adv Drug Delivery Rev 57:1666-1691. https://doi.org/10. 1016/j.addr.2005.07.003

Samadian H, Salehi M, Farzamfar S, Vaez A, Ehterami A, Sahrapeyma H, Goodarzi A, Ghorbani S (2018) In vitro and in vivo evaluation of electrospun cellulose acetate/ gelatin/hydroxyapatite nanocomposite mats for wound dressing applications. Artif Cells Nanomed Biotechnol 46:964-974. https://doi.org/10.1080/21691401.2018. 1439842

Sanz T, Laguna L, Salvador A (2015) Biscuit dough structural changes during heating: influence of shortening and cellulose ether emulsions. LWT-Food Sci Technol 62:962969. https://doi.org/10.1016/j.1wt.2015.02.036

Sarkar N (1979) Thermal gelation properties of methyl and hydroxypropyl methylcellulose. J Appl Polym Sci 24:1073-1087. https://doi.org/10.1002/app.1979. 070240420

Schoenbein C (1849) On ether glue, or liquor constringens; and its uses in surgery. Lancet 1333:289-290. https://doi.org/ 10.1016/s0140-6736(02)66777-7

Schuh V, Allard K, Herrmann K, Gibis M, Kohlus R, Weiss J (2013) Impact of carboxymethyl cellulose (CMC) and microcrystalline cellulose (MCC) on functional characteristics of emulsified sausages. Meat Sci 93:240-247. https://doi.org/10.1016/j.meatsci.2012.08.025 
Schunck M, Neumann C, Proksch E (2005) Artificial barrier repair in wounds by semi-occlusive foils reduced wound contraction and enhanced cell migration and reepithelization in mouse skin. J Invest Dermatol 125:1063-1071. https://doi.org/10.1111/j.0022-202x.2005.23890.x

Schütz K, Placht AM, Paul B, Brüggemeier S, Gelinsky M, Lode A (2017) Three-dimensional plotting of a cell-laden alginate/methylcellulose blend: towards biofabrication of tissue engineering constructs with clinically relevant dimensions. J Tissue Eng Regener Med 11:1574-1587. https://doi.org/10.1002/term.2058

Schweiger RG (1972) Polysaccharide sulfates. I. Cellulose sulfate with a high degree of substitution. Carbohydr Res 21:219-228. https://doi.org/10.1016/s0008-6215(00) $82148-5$

Sehaqui H, Zhou Q, Berglund LA (2011) Nanostructured biocomposites of high toughness - a wood cellulose nanofiber network in ductile hydroxyethylcellulose matrix. Soft Matter 7:7342-7350. https://doi.org/10.1039/ c1sm05325f

Seliktar D, Black RA, Vito RP, Nerem RM (2000) Dynamic mechanical conditioning of collagen-gel blood vessel constructs induces remodeling in vitro. Ann Biomed Eng 28:351-362. https://doi.org/10.1114/1.275

Septevani AA, Evans DA, Martin DJ, Annamalai PK (2018) Hybrid polyether-palm oil polyester polyol based rigid polyurethane foam reinforced with cellulose nanocrystal. Ind Crop Prod 112:378-388. https://doi.org/10.1016/j.ind crop.2017.12.032

Shahzadi T, Mehmood S, Irshad M, Anwar Z, Afroz A, Zeeshan N, Rashid U, Sughra K (2014) Advances in lignocellulosic biotechnology: a brief review on lignocellulosic biomass and cellulases. Adv Biosci Biotechnol 5:246-251. https://doi.org/10.4236/abb.2014.53031

Shao W, Liu H, Liu X, Sun H, Wang S, Zhang R (2015a) pHresponsive release behavior and anti-bacterial activity of bacterial cellulose-silver nanocomposites. Int $\mathrm{J}$ Biol Macromol 76:209-217. https://doi.org/10.1016/j.ijbio mac.2015.02.048

Shao W, Liu H, Liu X, Wang S, Wu J, Zhang R, Min H, Huang M (2015b) Development of silver sulfadiazine loaded bacterial cellulose/sodium alginate composite films with enhanced antibacterial property. Carbohydr Polym 132:351-358. https://doi.org/10.1016/j.carbpol.2015.06. 057

Shashoua Y, Bradley S, Daniels V (1992) Degradation of cellulose nitrate adhesive. Stud Conserv 37:113-119. https://doi.org/10.2307/1506403

Shefa AA, Amirian J, Kang HJ, Bae SH, Jung H-I, Choi H-j, Lee SY, Lee B-T (2017) In vitro and in vivo evaluation of effectiveness of a novel TEMPO-oxidized cellulose nanofiber-silk fibroin scaffold in wound healing. Carbohydr Polym 177:284-296. https://doi.org/10.1016/ j.carbpol.2017.08.130

Shi Z, Yang Q, Ono Y, Funahashi R, Saito T, Isogai A (2015) Creation of a new material stream from Japanese cedar resources to cellulose nanofibrils. React Funct Polym 95:19-24. https://doi.org/10.1016/j.reactfunctpolym.2015. 08.005

Shimizu M, Saito T, Isogai A (2016) Water-resistant and high oxygen-barrier nanocellulose films with interfibrillar cross-linkages formed through multivalent metal ions. J Membr Sci 500:1-7. https://doi.org/10.1016/j.memsci. 2015.11.002

Shinoda R, Saito T, Okita Y, Isogai A (2012) Relationship between length and degree of polymerization of TEMPOoxidized cellulose nanofibrils. Biomacromol 13:842-849. https://doi.org/10.1021/bm2017542

Shlieout G, Arnold K, Müller G (2002) Powder and mechanical properties of microcrystalline cellulose with different degrees of polymerization. AAPS PharmSciTech 3:45-54. https://doi.org/10.1208/pt030211

Shopsowitz KE, Qi H, Hamad WY, MacLachlan MJ (2010) Free-standing mesoporous silica films with tunable chiral nematic structures. Nature 468:422-425. https://doi.org/ 10.1038/nature09540

Singla R, Soni S, Kulurkar PM, Kumari A, Mahesh S, Patial V, Padwad YS, Yadav SK (2017) In situ functionalized nanobiocomposites dressings of bamboo cellulose nanocrystals and silver nanoparticles for accelerated wound healing. Carbohydr Polym 155:152-162

Siqueira G, Abdillahi H, Bras J, Dufresne A (2010) High reinforcing capability cellulose nanocrystals extracted from Syngonanthus nitens (Capim Dourado). Cellulose 17:289-298. https://doi.org/10.1007/s10570-009-9384-z

Sjöström E, Westermark U (1999) Chemical composition of wood and pulps: basic constituents and their distribution. Analytical methods in wood chemistry, pulping, and papermaking. Springer, pp 1-19. https://doi.org/10.1007/ 978-3-662-03898-7_1

Solway DR, Clark WA, Levinson DJ (2011) A parallel openlabel trial to evaluate microbial cellulose wound dressing in the treatment of diabetic foot ulcers. Int Wound J 8:6973. https://doi.org/10.1111/j.1742-481x.2010.00750.x

Soylak M, Divrikli U, Elci L, Dogan M (2002) Preconcentration of $\mathrm{Cr}(\mathrm{III}), \mathrm{Co}$ (II), $\mathrm{Cu}$ (II), $\mathrm{Fe}(\mathrm{III})$ and $\mathrm{Pb}(\mathrm{II})$ as calmagite chelates on cellulose nitrate membrane filter prior to their flame atomic absorption spectrometric determinations. Talanta 56:565-570. https://doi.org/10. 1016/s0039-9140(01)00575-6

Strømme M, Mihranyan A, Ek R (2002) What to do with all these algae? Mater Lett 57:569-572. https://doi.org/10. 1016/s0167-577x(02)00831-5

Šturcová A, Davies GR, Eichhorn SJ (2005) Elastic modulus and stress-transfer properties of tunicate cellulose whiskers. Biomacromol 6:1055-1061. https://doi.org/10.1021/ bm049291k

Su T, Wu Q-X, Chen Y, Zhao J, Cheng X-D, Chen J (2019) Fabrication of the polyphosphates patched cellulose sulfate-chitosan hydrochloride microcapsules and as vehicles for sustained drug release. Int J Pharm 555:291-302. https://doi.org/10.1016/j.ijpharm.2018.11.058

Sugiyama J, Vuong R, Chanzy H (1991) Electron diffraction study on the two crystalline phases occurring in native cellulose from an algal cell wall. Macromolecules 24:4168-4175. https://doi.org/10.1021/ma00014a033

Sulaeva I, Henniges U, Rosenau T, Potthast A (2015) Bacterial cellulose as a material for wound treatment: properties and modifications. A review. Biotechnol Adv 33:15471571. https://doi.org/10.1016/j.biotechadv.2015.07.009

Suliwarno A (2014) Hydrogel based on crosslinked methylcellulose prepared by electron beam irradiation for wound 
dressing application. Indones J Chem 14:262-268. https://doi.org/10.22146/ijc.21237

Sultan S, Mathew AP (2018) 3D printed scaffolds with gradient porosity based on a cellulose nanocrystal hydrogel. Nanoscale 10:4421-4431. https://doi.org/10.1039/ c7nr08966j

Sun Y, Cheng J (2002) Hydrolysis of lignocellulosic materials for ethanol production: a review. Bioresour Technol 83:111. https://doi.org/10.1002/chin.200301272

Supachok T, Quero F, Nogi M, Yano H, Young RJ, Lindström T, Sampson WW, Eichhorn SJ (2012) Effective Young's modulus of bacterial and microfibrillated cellulose fibrils in fibrous networks. Biomacromol 13:1340-1349. https://doi.org/10.1021/bm300042t

Suzuki T, Nakagami H (1999) Effect of crystallinity of microcrystalline cellulose on the compactability and dissolution of tablets. Eur J Pharm Biopharm 47:225-230. https://doi.org/10.1016/s0939-6411(98)00102-7

Svensson A, Nicklasson E, Harrah T, Panilaitis B, Kaplan D, Brittberg M, Gatenholm P (2005) Bacterial cellulose as a potential scaffold for tissue engineering of cartilage. Biomaterials 26:419-431. https://doi.org/10.1016/j.bioma terials.2004.02.049

Swain K, Pattnaik S, Mallick S, Chowdary KA (2009) Influence of hydroxypropyl methylcellulose on drug release pattern of a gastroretentive floating drug delivery system using a 32 full factorial design. Pharm Dev Technol 14:193-198. https://doi.org/10.1080/10837450802498902

Swamy BY, Yun Y-S (2015) In vitro release of metformin from iron (III) cross-linked alginate-carboxymethyl cellulose hydrogel beads. Int J Biol Macromol 77:114-119. https://doi.org/10.1016/j.ijbiomac.2015.03.019

Szczygielski K, Rapiejko P, Wojdas A, Jurkiewicz D (2010) Use of CMC foam sinus dressing in FESS. Eur Arch OtoRhino-Laryngol 267:537-540. https://doi.org/10.1007/ s00405-009-1117-2

Taepaiboon P, Rungsardthong U, Supaphol P (2007) Vitaminloaded electrospun cellulose acetate nanofiber mats as transdermal and dermal therapeutic agents of vitamin A acid and vitamin E. Eur J Pharm Biopharm 67:387-397. https://doi.org/10.1016/j.ejpb.2007.03.018

Tahara N, Tabuchi M, Watanabe K, Yano H, MoRINAGA Y, Yoshinaga F (1997) Degree of polymerization of cellulose from Acetobacter xylinum BPR2001 decreased by cellulase produced by the strain. Biosci Biotechnol Biochem 61:1862-1865. https://doi.org/10.1271/bbb.61.1862

Tanaka F, Iwata T (2006) Estimation of the elastic modulus of cellulose crystal by molecular mechanics simulation. Cellulose 13:509-517. https://doi.org/10.1007/s10570006-9068-x

Taokaew S, Phisalaphong M, B-mZ Newby (2015) Modification of bacterial cellulose with organosilanes to improve attachment and spreading of human fibroblasts. Cellulose 22:2311-2324. https://doi.org/10.1007/s10570-015-0651$\mathrm{x}$

Tarchoun AF, Trache D, Klapötke TM (2019) Microcrystalline cellulose from Posidonia oceanica brown algae: extraction and characterization. Int J Biol Macromol 138:837-845. https://doi.org/10.1016/j.ijbiomac.2019.07.176

Tashiro K, Kobayashi M (1991) Theoretical evaluation of three-dimensional elastic constants of native and regenerated celluloses: role of hydrogen bonds. Polymer 32:1516-1526. https://doi.org/10.1016/0032-3861(91) 90435-1

Teixeira MA, Paiva MC, Amorim MTP (2020) Electrospun nanocomposites containing cellulose and its derivatives modified with specialized biomolecules for an enhanced wound healing. Nanomaterials 10:557. https://doi.org/10. 3390/nano10030557

Thirumala S, Gimble JM, Devireddy RV (2013) Methylcellulose based thermally reversible hydrogel system for tissue engineering applications. Cells 2:460-475. https://doi.org/ 10.3390/cells2030460

Thoorens G, Krier F, Leclercq B, Carlin B, Evrard B (2014) Microcrystalline cellulose, a direct compression binder in a quality by design environment - a review. Int $\mathrm{J}$ Pharm 473:64-72. https://doi.org/10.1016/j.ijpharm.2014.06.055

Thygesen A, Oddershede J, Lilholt H, Thomsen AB, Ståhl K (2005) On the determination of crystallinity and cellulose content in plant fibres. Cellulose 12:563-576. https://doi. org/10.1007/s10570-005-9001-8

Tibolla H, Pelissari FM, Rodrigues MI, Menegalli FC (2017) Cellulose nanofibers produced from banana peel by enzymatic treatment: study of process conditions. Ind Crops Prod 95:664-674. https://doi.org/10.1016/j.indcrop. 2016.11.035

Tilki T, Yavuz M, Karabacak Ç, Çabuk M, Ulutürk M (2010) Investigation of electrorheological properties of biodegradable modified cellulose/corn oil suspensions. Carbohydr Res 345:672-679. https://doi.org/10.1016/ j.carres.2009.12.025

Tohamy KM, Mabrouk M, Soliman IE, Beherei HH, Aboelnasr MA (2018) Novel alginate/hydroxyethyl cellulose/hydroxyapatite composite scaffold for bone regeneration: in vitro cell viability and proliferation of human mesenchymal stem cells. Int J Biol Macromol 112:448-460. https://doi.org/10.1016/j.ijbiomac.2018.01.181

Torres-Rendon JG, Femmer T, De Laporte L, Tigges T, Rahimi $\mathrm{K}$, Gremse F, Zafarnia S, Lederle W, Ifuku S, Wessling M (2015) Bioactive gyroid scaffolds formed by sacrificial templating of nanocellulose and nanochitin hydrogels as instructive platforms for biomimetic tissue engineering. Adv Mater 27:2989-2995. https://doi.org/10.1002/adma. 201405873

Trache D, Hussin MH, Haafiz MM, Thakur VK (2017) Recent progress in cellulose nanocrystals: sources and production. Nanoscale 9:1763-1786. https://doi.org/10.1039/ c6nr09494e

Trache D, Thakur VK, Boukherroub R (2020) Cellulose nanocrystals/graphene hybrids-A promising new class of materials for advanced applications. Nanomaterials 10:1523. https://doi.org/10.3390/nano10081523

Turbak AF, Snyder FW, Sandberg KR (1983) Microfibrillated cellulose, a new cellulose product: properties, uses and commercial potential. J Appl Polym Sci Appl Polym Syma 37:815-827

Uehara T, Sakata I (1990) Effect of corona discharge treatment on cellulose prepared from beech wood. J Appl Polym Sci 41:1695-1706. https://doi.org/10.1002/app.1990. 070410728

Ul-Islam M, Khan T, Khattak WA, Park JK (2013) Bacterial cellulose-MMTs nanoreinforced composite films: novel 
wound dressing material with antibacterial properties. Cellulose 20:589-596. https://doi.org/10.1007/s10570012-9849-3

Vargas F, González Z, Sánchez R, Jiménez L, Rodríguez A (2012) Cellulosic pulps of cereal straws as raw material for the manufacture of ecological packaging. BioResources 7:4161-4170

Vieira JG, Rodrigues Filho G, Meireles CdS, Faria FA, Gomide DD, Pasquini D, Cruz SFd, Assunção R, Motta LAdC (2012) Synthesis and characterization of methylcellulose from cellulose extracted from mango seeds for use as a mortar additive. Polímeros 22:80-87. https://doi. org/10.1590/s0104-14282012005000011

Viera RG, Rodrigues Filho G, de Assunção RM, Meireles CdS, Vieira JG, de Oliveira GS (2007) Synthesis and characterization of methylcellulose from sugar cane bagasse cellulose. Carbohydr Polym 67:182-189. https://doi.org/ 10.1016/j.carbpol.2006.05.007

Vikingsson L, Claessens B, Gómez-Tejedor JA, Ferrer GG, Ribelles JG (2015) Relationship between micro-porosity, water permeability and mechanical behavior in scaffolds for cartilage engineering. J Mech Behav Biomed Mater 48:60-69. https://doi.org/10.1016/j.jmbbm.2015.03.021

Vitz J, Erdmenger T, Haensch C, Schubert US (2009) Extended dissolution studies of cellulose in imidazolium based ionic liquids. Green Chem 11:417-424. https://doi.org/10. 1039/b818061j

Vuoriluoto M, Orelma H, Lundahl M, Borghei M, Rojas OJ (2017) Filaments with affinity binding and wet strength can be achieved by spinning bifunctional cellulose nanofibrils. Biomacromol 18:1803-1813. https://doi.org/ 10.1021/acs.biomac.7b00256.s001

Wada M, Ike M, Tokuyasu K (2010) Enzymatic hydrolysis of cellulose I is greatly accelerated via its conversion to the cellulose II hydrate form. Polym Degrad Stab 95:543548. https://doi.org/10.1016/j.polymdegradstab.2009.12. 014

Wågberg L, Decher G, Norgren M, Lindström T, Ankerfors M, Axnäs K (2008) The build-up of polyelectrolyte multilayers of microfibrillated cellulose and cationic polyelectrolytes. Langmuir 24:784-795. https://doi.org/ 10.1021/la702481v.s002

Walther A, Timonen JV, Díez I, Laukkanen A, Ikkala O (2011) Multifunctional high-performance biofibers based on wetextrusion of renewable native cellulose nanofibrils. Adv Mater 23:2924-2928. https://doi.org/10.1002/adma. 201100580

Walther A, Lossada F, Benselfelt T, Kriechbaum K, Berglund LA, Ikkala O, Saito T, Wågberg L, Bergström L (2020) Best practice for reporting wet mechanical properties of nanocellulose-based materials. Biomacromol 21:25362540. https://doi.org/10.1021/acs.biomac.0c00330

Wan L, Chui W (1995) Deviation of the ratio of drugs in a twocomponent mixture encapsulated in cellulose phthalate microspheres. J Microencapsulation 12:417-423. https://doi.org/10.3109/02652049509087254

Wang Y, Wei X, Li J, Wang Q, Wang F, Kong L (2013) Homogeneous isolation of nanocellulose from cotton cellulose by high pressure homogenization. J Mater Sci Chem Eng 1:49-52. https://doi.org/10.4236/msce.2013. 15010
Wang W, Li F, Yu J, Navard P, Budtova T (2015) Influence of substitution on the rheological properties and gelation of hydroxyethyl cellulose solution in $\mathrm{NaOH}-$ water solvent. Carbohydr Polym 124:85-89. https://doi.org/10.1016/ j.carbpol.2015.01.065

Wang X, Cheng F, Liu J, Smått J-H, Gepperth D, Lastusaari M, Xu C, Hupa L (2016) Biocomposites of copper-containing mesoporous bioactive glass and nanofibrillated cellulose: biocompatibility and angiogenic promotion in chronic wound healing application. Acta Biomater 46:286-298. https://doi.org/10.1016/j.actbio.2016.09.021

Wang M, Li W, You C, Wang Q, Zeng X, Chen M (2017) Triboelectric nanogenerator based on 317L stainless steel and ethyl cellulose for biomedical applications. RSC Adv 7:6772-6779. https://doi.org/10.1039/c6ra28252k

Wang B, Lv X, Chen S, Li Z, Yao J, Peng X, Feng C, Xu Y, Wang H (2018) Use of heparinized bacterial cellulose based scaffold for improving angiogenesis in tissue regeneration. Carbohydr Polym 181:948-956. https://doi. org/10.1016/j.carbpol.2017.11.055

Wardhono EY, Kanani N, Alfirano A (2020) A simple process of isolation microcrystalline cellulose using ultrasonic irradiation. J Disper Sci Technol 41:1217-1226. https://doi.org/10.1080/01932691.2019.1614947

Wasilewska K, Winnicka K (2019) Ethylcellulose-a pharmaceutical excipient with multidirectional application in drug dosage forms development. Materials 12:3386. https://doi.org/10.3390/ma12203386

Wong TW, Ramli NA (2014) Carboxymethylcellulose film for bacterial wound infection control and healing. Carbohydr Polym 112:367-375. https://doi.org/10.1016/j.carbpol. 2014.06.002

Wsoo MA, Shahir S, Bohari SPM, Nayan NHM, Abd Razak SI (2020) A review on the properties of electrospun cellulose acetate and its application in drug delivery systems: a new perspective. Carbohydr Res 491:107978. https://doi.org/ 10.1016/j.carres.2020.107978

Wu J, Liang S, Dai H, Zhang X, Yu X, Cai Y, Zhang L, Wen $\mathrm{N}$, Jiang B, Xu J (2010) Structure and properties of cellulose/chitin blended hydrogel membranes fabricated via a solution pre-gelation technique. Carbohydr Polym 79:677-684. https://doi.org/10.1016/j.carbpol.2009.09. 022

Wu Q, Meng Y, Concha K, Wang S, Li Y, Ma L, Fu S (2013) Influence of temperature and humidity on nano-mechanical properties of cellulose nanocrystal films made from switchgrass and cotton. Ind Crop Prod 48:28-35. https://doi.org/10.1016/j.indcrop.2013.03.032

Wu C-N, Fuh S-C, Lin S-P, Lin Y-Y, Chen H-Y, Liu J-M, Cheng K-C (2018) TEMPO-oxidized bacterial cellulose pellicle with silver nanoparticles for wound dressing. Biomacromol 19:544-554. https://doi.org/10.1021/acs. biomac.7b01660

Wutticharoenmongkol P, Hannirojram P, Nuthong P (2019) Gallic acid-loaded electrospun cellulose acetate nanofibers as potential wound dressing materials. Polym Adv Technol 30:1135-1147. https://doi.org/10.1002/pat.4547

Xie Y-L, Wang M-J, Yao S-J (2009) Preparation and characterization of biocompatible microcapsules of sodium cellulose sulfate/chitosan by means of layer-by-layer self- 
assembly. Langmuir 25:8999-9005. https://doi.org/10. 1021/la9014338

Xiong R, Hu K, Grant AM, Ma R, Xu W, Lu C, Zhang X, Tsukruk VV (2016) Ultrarobust transparent cellulose nanocrystal-graphene membranes with high electrical conductivity. Adv Mater 28:1501-1509. https://doi.org/ 10.1002/adma.201504438

Xiquan L, Tingzhu Q, Shaoqui Q (1990) Kinetics of the carboxymethylation of cellulose in the isopropyl alcohol system. Acta Polym 41:220-222. https://doi.org/10.1002/ actp.1990.010410406

Xu W, Reddy N, Yang Y (2009) Extraction, characterization and potential applications of cellulose in corn kernels and Distillers' dried grains with solubles (DDGS). Carbohydr Polym 76:521-527. https://doi.org/10.1016/j.carbpol. 2008.11.017

Xu A, Wang J, Wang H (2010) Effects of anionic structure and lithium salts addition on the dissolution of cellulose in 1-butyl-3-methylimidazolium-based ionic liquid solvent systems. Green Chem 12:268-275. https://doi.org/10. 1039/b916882f

Yamada T, Saito N, Imai T, Otagiri M (1999) Effect of grinding with hydroxypropyl cellulose on the dissolution and particle size of a poorly water-soluble drug. Chem Pharm Bull 47:1311-1313. https://doi.org/10.1248/cpb. 47.1311

Yamamoto H, Horii F, Hirai A (1996) In situ crystallization of bacterial cellulose II. Influences of different polymeric additives on the formation of celluloses I $\alpha$ and I $\beta$ at the early stage of incubation. Cellulose 3:229-242. https://doi.org/10.1007/bf02228804

Yan H, Chen X, Feng M, Shi Z, Zhang W, Wang Y, Ke C, Lin Q (2019) Entrapment of bacterial cellulose nanocrystals stabilized Pickering emulsions droplets in alginate beads for hydrophobic drug delivery. Colloids Surf B 177:112120. https://doi.org/10.1016/j.colsurfb.2019.01.057

Yang D, Peng X, Zhong L, Cao X, Chen W, Zhang X, Liu S, Sun R (2014) "Green" films from renewable resources: properties of epoxidized soybean oil plasticized ethyl cellulose films. Carbohydr Polym 103:198-206. https://doi.org/10.1016/j.carbpol.2013.12.043

Yang Y, Guo Y, Sun R, Wang X (2016) Self-assembly and $\beta$ carotene loading capacity of hydroxyethyl cellulose-graftlinoleic acid nanomicelles. Carbohydr Polym 145:56-63. https://doi.org/10.1016/j.carbpol.2016.03.012

Ye J, Si J, Cui Z, Wang Q, Peng K, Chen W, Peng X, Chen SC (2017) Surface modification of electrospun TPU nanofiber scaffold with CNF particles by ultrasound-assisted technique for tissue engineering. Macromol Mater Eng 302:1700277. https://doi.org/10.1002/mame.201700277

Yu H-Y, Qin Z-Y, Liu Y-N, Chen L, Liu N, Zhou Z (2012) Simultaneous improvement of mechanical properties and thermal stability of bacterial polyester by cellulose nanocrystals. Carbohydr Polym 89:971-978. https://doi. org/10.1016/j.carbpol.2012.04.053

Yu D-G, Li X-Y, Wang X, Chian W, Liao Y-Z, Li Y (2013) Zero-order drug release cellulose acetate nanofibers prepared using coaxial electrospinning. Cellulose 20:379389. https://doi.org/10.1007/s10570-012-9824-Z

Yu Y, Zhang Y, Yang X, Liu H, Shao L, Zhang X, Yao J (2015) Biodegradation process and yellowing mechanism of an ecofriendly superabsorbent based on cellulose from flax yarn wastes. Cellulose 22:329-338. https://doi.org/10. 1007/s10570-014-0531-9

Zambrano F, Starkey H, Wang Y, de Assis CA, Venditti R, Pal L, Jameel H, Hubbe MA, Rojas OJ, Gonzalez R (2020) Using micro-and nanofibrillated cellulose as a means to reduce weight of paper products: a review. BioResources $15: 4553-4590$

Zhang LM, Chen LQ (2002) Water-soluble grafted polysaccharides containing sulfobetaine groups: synthesis and characterization of graft copolymers of hydroxyethyl cellulose with 3-dimethyl (methacryloyloxyethyl) ammonium propane sulfonate. J Appl Polym Sci 83:2755-2761. https://doi.org/10.1002/app.10191

Zhang Y, Tang S, Zhang T (2017) Homogeneous alkalization of cellulose in $\mathrm{N}$-methylmorpholine-N-oxide/water solution. Cellulose 24:1235-1245. https://doi.org/10.1007/ s10570-017-1195-Z

Zhang J, Xu Y, Liu T, Min J, Ma Y, Song Y, Lu J, Mi W, Wang Y, Li H (2019) In vivo construction of lymphoid node by implantation of adipose-derived stromal cells with hydroxypropyl methyl cellulose hydrogel in BALB/c nude mice. Organogenesis 15:85-99. https://doi.org/10. 1080/15476278.2019.1656994

Zhao Y, Li J (2014) Excellent chemical and material cellulose from tunicates: diversity in cellulose production yield and chemical and morphological structures from different tunicate species. Cellulose 21:3427-3441. https://doi.org/ 10.1007/s10570-014-0348-6

Zhao Y, Xu C, Xing C, Shi X, Matuana LM, Zhou H, Ma X (2015a) Fabrication and characteristics of cellulose nanofibril films from coconut palm petiole prepared by different mechanical processing. Ind Crop Prod 65:96101. https://doi.org/10.1016/j.indcrop.2014.11.057

Zhao Y, Zhang Y, Lindström ME, Li J (2015b) Tunicate cellulose nanocrystals: preparation, neat films and nanocomposite films with glucomannans. Carbohydr Polym 117:286-296. https://doi.org/10.1016/j.carbpol. 2014.09.020

Zhao Y, Moser C, Lindström ME, Henriksson G, Li J (2017) Cellulose nanofibers from softwood, hardwood, and tunicate: preparation-structure-film performance interrelation. ACS Appl Mater Interfaces 9:13508-13519. https://doi.org/10.1021/acsami.7b01738

Zheng X, Gandour RD, Edgar KJ (2014) Remarkably regioselective deacylation of cellulose esters using tetraalkylammonium salts of the strongly basic hydroxide ion. Carbohydr Polym 111:25-32. https://doi.org/10.1016/ j.carbpol.2014.04.014

Zhong C, Zhang G-C, Liu M, Zheng X-T, Han P-P, Jia S-R (2013) Metabolic flux analysis of Gluconacetobacter xylinus for bacterial cellulose production. Appl Microbiol Biotechnol 97:6189-6199. https://doi.org/10.1007/ s00253-013-4908-8

Zhou S, Nyholm L, Strømme M, Wang Z (2019) Cladophora cellulose: unique biopolymer nanofibrils for emerging energy, environmental, and life science applications. Acc Chem Res 52:2232-2243. https://doi.org/10.1021/acs.ac counts.9b00215

Zhu C, Koutsomitopoulou AF, Eichhorn SJ, van Duijneveldt JS, Richardson RM, Nigmatullin R, Potter KD (2018a) 
High stiffness cellulose fibers from low molecular weight microcrystalline cellulose solutions using DMSO as cosolvent with ionic liquid. Macromol Mater Eng 303:1800029. https://doi.org/10.1002/mame.201800029

Zhu G, Xu H, Dufresne A, Lin N (2018b) High-adsorption, self-extinguishing, thermal, and acoustic-resistance aerogels based on organic and inorganic waste valorization from cellulose nanocrystals and red mud. ACS Sustain Chem Eng 6:7168-7180. https://doi.org/10.1021/ac ssuschemeng.8b01244.s001

Zhuo F, Liu X, Gao Q, Wang Y, Hu K, Cai Q (2017) Injectable hyaluronan-methylcellulose composite hydrogel crosslinked by polyethylene glycol for central nervous system tissue engineering. Mater Sci Eng, C 81:1-7. https://doi.org/10.1016/j.msec.2017.07.029

Zmejkoski D, Spasojević D, Orlovska I, Kozyrovska N, Soković M, Glamočlija J, Dmitrović S, Matović B, Tasić N, Maksimović V (2018) Bacterial cellulose-lignin composite hydrogel as a promising agent in chronic wound healing. Int J Biol Macromol 118:494-503. https://doi.org/10.1016/j.ijbiomac.2018.06.067

Zolkefpeli SM, Wong T (2013) Design of microcrystalline cellulose-free alginate spheroids by extrusionspheronization technique. Chem Eng Res Des 91:24372446. https://doi.org/10.1016/j.cherd.2013.04.017

Zulkifli FH, Hussain FSJ, Zeyohannes SS, Rasad MSBA, Yusuff MM (2017) A facile synthesis method of hydroxyethyl cellulose-silver nanoparticle scaffolds for skin tissue engineering applications. Mater Sci Eng, C 79:151-160. https://doi.org/10.1016/j.msec.2017.05.028

Publisher's Note Springer Nature remains neutral with regard to jurisdictional claims in published maps and institutional affiliations. 